Universidad

:

BIBLIOTECA

Document downloaded from the institutional repository of the University of Alcala: https://ebuah.uah.es/dspace/

This is a postprint version of the following published document:

Zapata, F. \& García-Ruiz, C., 2018. The discrimination of 72 nitrate, chlorate and perchlorate salts using IR and Raman spectroscopy. Spectrochimica Acta Part A: Molecular and Biomolecular Spectroscopy, 189, pp.535-542.

Available at https://doi.org/10.1016/i.saa.2017.08.058

(C) 2017 Elsevier
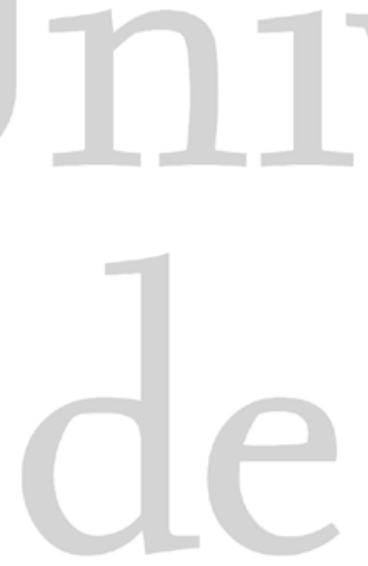

(Article begins on next page)

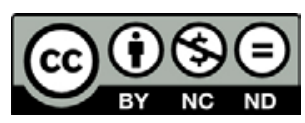

This work is licensed under a

Creative Commons Attribution-NonCommercial-NoDerivatives

4.0 International License. 


\title{
The discrimination of 72 nitrate, chlorate and perchlorate salts using IR and Raman spectroscopy
}

\author{
Félix Zapata, Carmen García-Ruiz*
}

Department of Analytical Chemistry, Physical Chemistry and Chemical Engineering, University of Alcalá, Ctra. Madrid-Barcelona km 33.600, 28871 Alcalá de Henares (Madrid), Spain

Email: carmen.gruiz@uah.es; felix.zapata@uah.es

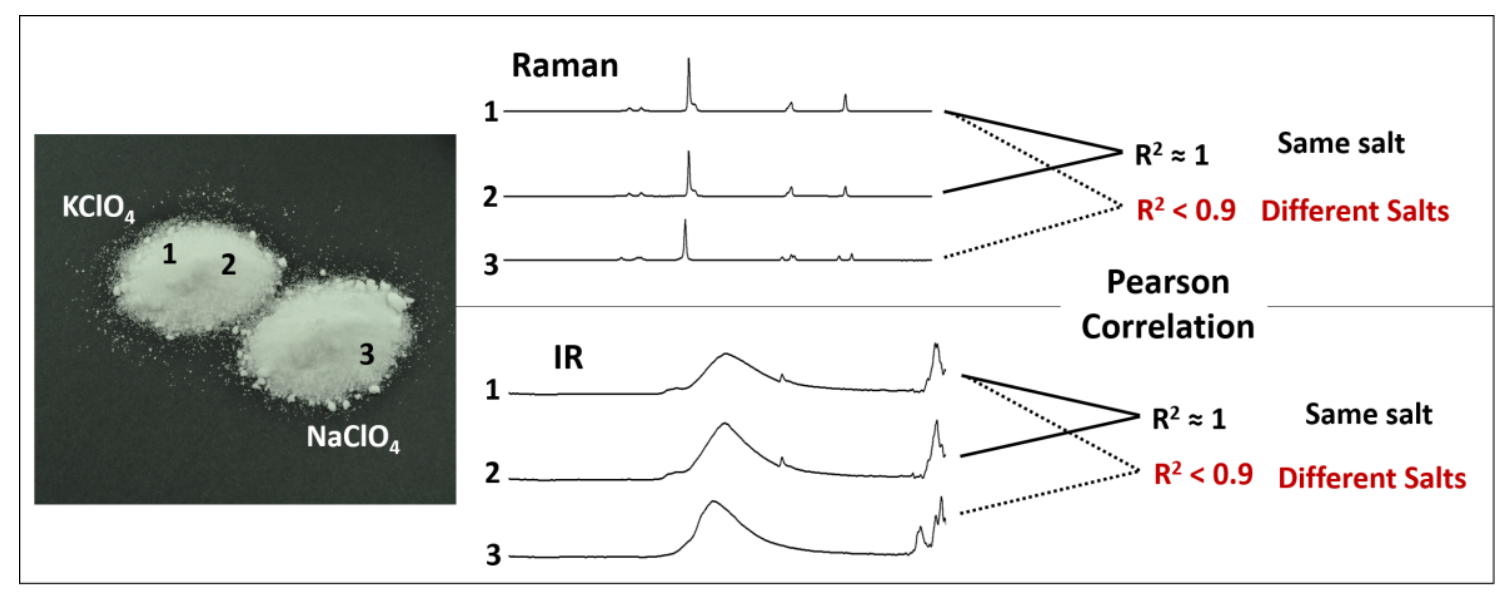

Cite: F. Zapata, C. García-Ruiz, The discrimination of 72 nitrate, chlorate and perchlorate salts using IR and Raman spectroscopy, Spectrochim. Acta A 189 (2018) 535-542. DOI: 10.1016/j.saa.2017.08.058

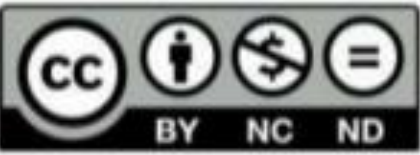




\begin{abstract}
Inorganic oxidizing energetic salts including nitrates, chlorates and perchlorates are widely used in the manufacture of not only licit pyrotechnic compositions, but also illicit homemade explosive mixtures. Their identification in forensic laboratories is usually accomplished by either capillary electrophoresis or ion chromatography, with the disadvantage of dissociating the salt into its ions. On the contrary, vibrational spectroscopy, including IR and Raman, enables the non-invasive identification of the salt, i.e. avoiding its dissociation. This study focuses on the discrimination of all nitrate, chlorate and perchlorate salts that are commercially available, using both Raman and IR spectroscopy, with the aim of testing whether every salt can be unequivocally identified. Besides the visual spectra comparison by assigning every band with the corresponding molecular vibrational mode, a statistical analysis based on Pearson correlation was performed to ensure an objective identification, either using Raman, IR or both. Positively, 25 salts (out of 72) were unequivocally identified using Raman, 30 salts when using IR and 44 when combining both techniques. Negatively, some salts were undistinguishable even using both techniques demonstrating there are some salts that provide very similar Raman and IR spectra.
\end{abstract}

Keywords: Chlorates; Nitrates; Perchlorates; IR; Raman; Pearson correlation. 


\section{Introduction}

Inorganic oxidizing energetic salts such as nitrates, chlorates and perchlorates, are of great forensic interest due to their usual and major presence in charge compositions of a large number of improvised explosive devices [1-4]. These salts are commercially accessible (either on their own or as part of the charge of pyrotechnic devices), and, dreadfully, easy “do-it-yourself" recipes to make damaging explosive compositions are freely available [1-7]. In this respect, rapid and selective methodologies to determine them are necessary because forensic investigators may draw relevant conclusions regarding the source, intention, or even the terrorist group or criminals involved; according to the explosive which has been used $[1,3]$.

In any case, it is useful to determine the particular salt, i.e. determining both anion and cation. However, current methodologies used in forensic laboratories usually involve an aqueous extraction (in which the inorganic salts dissociate into their anions and cations) followed by either capillary electrophoresis [8-13] or ion chromatography determination [14-19]. The anions are usually determined because they provide the most relevant information about the explosive [19], i.e. whether the explosive is mostly based on a chlorate, a perchlorate or a nitrate salt. More comprehensive results are obtained when using dual working modes, in which both, anions and cations, are determined $[9,18,19]$. Nevertheless, it is important to remark that, using either CE or IC, anions and cations, if both are measured, are separately identified (not constituting the salt), which may induce to misleading results when trying to match them, especially when various cationic and anionic species are involved.

Recently, some research studies have preliminary tested the suitability of spectroscopic techniques, mainly, IR and Raman spectroscopy, to discriminate few of these salts [2024]. Briefly, using either IR [20] or Raman spectroscopy [21], potassium nitrate, potassium chlorate, and potassium perchlorate have been demonstrated to provide different spectra according to their different bands: 1370 and $823 \mathrm{~cm}^{-1}$ for nitrate, 955 , 933, 613 and $487 \mathrm{~cm}^{-1}$ for chlorate, and 1060, 940 and $621 \mathrm{~cm}^{-1}$ for perchlorate using IR [20]; or 1047 and $712 \mathrm{~cm}^{-1}$ for nitrate, $976,937,617$ and $485 \mathrm{~cm}^{-1}$ for chlorate, and 940 , 628 and $462 \mathrm{~cm}^{-1}$ for perchlorate using Raman [21]. Likewise, sodium nitrate and sodium chlorate have also been verified to have different Raman spectra with bands located at 1383, 1065 and $722 \mathrm{~cm}^{-1}$ versus 985, 934, 621 and $479 \mathrm{~cm}^{-1}$, respectively [21]; or 
ammonium nitrate and ammonium perchlorate, whose main bands are located at 1044 and $940 \mathrm{~cm}^{-1}$, respectively [22].

In sum, it has been demonstrated that inorganic salts with different anions are easily discriminated through IR or Raman spectroscopy. The characteristic bands due to the vibrational modes of the anion enable the discrimination of salts. IR and Raman spectroscopy are vibrational techniques, i.e. they provide a characteristic spectral signature of each molecule according to the vibrational modes of their covalent chemical bonds $[25,26]$. This is ideal to discriminate salts whose anions contain covalent bonds such as nitrates, chlorates and perchlorates. In fact, nitrates can be distinguished from chlorates and perchlorates according to their completely different bonds $(\mathrm{N}-\mathrm{O}$ versus $\mathrm{Cl}-\mathrm{O}$ ); but also, chlorates can be differentiated from perchlorates due to their different number of atoms and molecular geometry which lead to different vibrational modes. In brief, vibrational spectroscopic techniques allow to discriminate nitrates, chlorates and perchlorates among each other [25,26].

However, is vibrational spectroscopy suitable to discriminate salts that have the same anion? Interestingly, preliminary studies have verified that both, IR and Raman spectra of inorganic salts are influenced somehow by the cation. For instance, the nitrate salts of three different cations such as ammonium, potassium and sodium, have significant differences in their Raman spectra even though their spectral bands are due to the nitrate $[21,23]$. Ammonium may provide additional specific bands due to their own covalent bonds $(\mathrm{N}-\mathrm{H})$ which would discriminate it, but sodium nitrate and potassium nitrate which do not have covalent bonds except those from nitrate also provide different spectra. Concretely, the band due to $\mathrm{N}-\mathrm{O}$ stretching is shifted in the spectrum of each salt (1041 $\mathrm{cm}^{-1}$ for ammonium, $1047 \mathrm{~cm}^{-1}$ for potassium and $1065 \mathrm{~cm}^{-1}$ for sodium nitrate [21], in such a way that this shift is significant enough to spectrally resolve ammonium and potassium nitrate even in mixtures [24], which is a crucial current challenge in forensics). In the same way, significant spectral differences between potassium and barium nitrate have been evidenced in their respective IR spectra (with bands located at 1370 and 823 $\mathrm{cm}^{-1}$ for potassium and 1413, 1335, 814 and $728 \mathrm{~cm}^{-1}$ for barium nitrate [20]); or between Sodium and potassium chlorate whose bands in their Raman spectra are slightly shifted among each other $\left(985,934,621\right.$ and $479 \mathrm{~cm}^{-1}$ for sodium chlorate versus 976, 937, 617 and $485 \mathrm{~cm}^{-1}$ for potassium chlorate [21]). But, does it mean, for instance, that all nitrate salts provide significant spectral differences to be distinguished? Or do nitrate salts with 
similar cations provide too slight spectral differences in such a way that they do not enable their discrimination?

In order to solve these questions, this study aims to evaluate all nitrate, chlorate and perchlorate salts commercially available using IR and Raman spectroscopy.

\section{Experimental section}

\subsection{Inorganic Oxidizing Salts}

In this study, 72 inorganic salts including nitrates (46), chlorates (4) and perchlorates (22) were considered. They were purchased at ACS grade (purity over 98\%) either from Sigma-Aldrich or Alfa-Aesar. Salts were purchased anhydrous when possible. However, some salts were only available in their hydrated form and, particularly, ammonium perchlorate was only available in aqueous solution.

The chlorate salts analysed were sodium chlorate, potassium chlorate, barium chlorate monohydrate and silver chlorate.

The perchlorate salts analysed were lithium perchlorate trihydrate, sodium perchlorate, sodium perchlorate monohydrate, potassium perchlorate, magnesium perchlorate, calcium perchlorate tetrahydrate, strontium perchlorate trihydrate, barium perchlorate trihydrate, cerium (III) perchlorate hexahydrate, manganese (II) perchlorate hexahydrate, iron (II) perchlorate hydrate, iron (III) perchlorate hydrate, cobalt (II) perchlorate hexahydrate, nickel (II) perchlorate hexahydrate, copper (II) perchlorate hexahydrate, silver perchlorate, zinc perchlorate hexahydrate, cadmium perchlorate hydrate, mercury (II) perchlorate hydrate, aluminium perchlorate nonahydrate, lead (II) perchlorate hydrate and ammonium perchlorate solution $\left(1 \mathrm{M}\right.$ in $\left.\mathrm{H}_{2} \mathrm{O}\right)$.

Nitrate salts analysed were lithium nitrate, sodium nitrate, potassium nitrate, rubidium nitrate, caesium nitrate, magnesium nitrate hexahydrate, calcium nitrate tetrahydrate, strontium nitrate, barium nitrate, scandium nitrate hydrate, yttrium (III) nitrate hexahydrate, lanthanum (III) nitrate hexahydrate, cerium (III) nitrate hexahydrate, praseodymium (III) nitrate hexahydrate, neodymium (III) nitrate hexahydrate, samarium (III) nitrate hexahydrate, europium (III) nitrate pentahydrate, gadolinium (III) nitrate hexahydrate, terbium (III) nitrate pentahydrate, dysprosium (III) nitrate hydrate, holmium 
(III) nitrate pentahydrate, erbium (III) nitrate pentahydrate, thulium (III) nitrate hydrate, ytterbium (III) nitrate pentahydrate, lutetium (III) nitrate hydrate, chromium (III) nitrate nonahydrate, manganese (II) nitrate tetrahydrate, iron (III) nitrate nonahydrate, cobalt (II) nitrate hexahydrate, nickel (II) nitrate hexahydrate, palladium (II) nitrate dihydrate, copper (II) nitrate trihydrate, silver nitrate, zinc nitrate hexahydrate, cadmium nitrate tetrahydrate, mercury (I) nitrate dihydrate, mercury (II) nitrate monohydrate, aluminium nitrate nonahydrate, gallium nitrate hydrate, indium (III) nitrate hydrate, thallium (I) nitrate, thallium (III) nitrate trihydrate, lead (II) nitrate, ammonium nitrate, cerium (IV) ammonium nitrate and bismuth (III) nitrate pentahydrate.

\subsection{Instrumentation for Raman and IR analysis}

Raman analysis was performed with a Thermo Scientific DXR Raman microscope using the Thermo Scientific Omnic for dispersive Raman 8 software (Waltham, MA). Raman measurements were performed using a $532 \mathrm{~nm}$ excitation wavelength, $10 \mathrm{~mW}$ power, $10 \times$ magnification objective ( $3.1 \mu \mathrm{m}$ diameter spot size) and 400 lines $\mathrm{mm}^{-1} 1$ grating, from 2000 to $400 \mathrm{~cm}^{-1}$, with a spectral resolution of 2 (data spacing of $0.964 \mathrm{~cm}^{-1}$ ). The spectra acquisition for all samples involved the accumulation of 6 scans of $5 \mathrm{~s}$ per scan. Five replicates collected from 5 different spots were analysed per sample (5 Raman spectra per salt).

A Thermo Scientific FT-IR Nicolet IS10 spectrometer equipped with smart ITR module for ATR measurements and controlled through the Omnic ${ }^{\mathrm{TM}}$ spectroscopy for IR spectroscopy 9 (Waltham, MA, USA) was used for IR analysis. IR spectra were collected from 3000 to $600 \mathrm{~cm}^{-1}$, with a resolution of 4 (data spacing of $0.483 \mathrm{~cm}^{-1}$ ) and 16 scans. Five replicates were analysed per sample by placing fresh powder on the ATR diamond crystal for each replicate (5 IR spectra per salt).

These Raman and IR parameters were fixed by demonstrating they were suitable to obtain Raman spectra of high signal-to noise ratio for most of the salts.

\subsection{Data Analysis}

Besides the visual spectra comparison, multivariate statistical analysis using Pearson Correlation (r) was performed to discriminate the salts.

First, the Raman shift and wavenumber values of the bands due to the chemical vibrational modes of nitrates, chlorates and perchlorates were visually compared and 
studied (see Sections 3.1 and 3.2 of Results and Discussion). Afterwards, spectra were statistically compared using Pearson correlation. First of all, the optimum spectral range (in terms of selectivity for discriminating the salts) was selected after testing different potentially suitable ranges (i.e. containing always the most intense and characteristic bands). Either two optimum ranges were suitable for Raman, $1500-400 \mathrm{~cm}^{-1}$ or 1100 $400 \mathrm{~cm}^{-1}$, since both provided the same results in terms of the number of unequivocally identified salts; whereas the optimum range for IR was from 1500 to $600 \mathrm{~cm}^{-1}$. It should be noted that the IR range was limited to $600 \mathrm{~cm}^{-1}$ because of the instrumental features. Then, spectra were normalized between 0 and 1 (using range normalization). Finally, the Pearson correlation analysis was performed. In order to study the selectivity, the intraand inter-variability between every salt were evaluated. The intra-variability of each salt was accounted by calculating the Pearson correlation among the 5 spectra collected for each salt (10 combinations) avoiding the correlation of each spectrum with itself. Then, the inter-variability between two salts was accounted by calculating the Pearson Correlation between the 5 spectra of salt 1 and the 5 spectra of salt 2 ( 25 combinations). These calculations were iteratively performed for every salt using MatLab R2016b (Mathworks, USA) through a homemade algorithm based on the "corrcoef" function. Finally, the identification/discrimination of salts was automatically performed in MatLab by comparing the intra-variability and inter-variability Pearson values of all salts using basic mathematical operations mainly based in "less/greater than" comparisons and conditional statement loops.

\section{Results and discussion}

\subsection{Discrimination of Energetic Salts Using Raman Spectroscopy}

The Raman spectra of these inorganic salts were dominated by those bands which are due to the vibrational modes of the anion, since it contains the covalent bonds $\mathrm{N}-\mathrm{O}$ or $\mathrm{Cl}-\mathrm{O}$.

In brief, nitrate salts displayed two main bands in their Raman spectra, which were due to the $\mathrm{N}-\mathrm{O}$ symmetric stretching vibration and the $\mathrm{N}-\mathrm{O}$ in plane deformation. The symmetric stretching vibration of nitrate $\left(v_{1}\left(A^{\prime}\right)\right)$, which appeared in most salts as a unique band or two separate bands (probably because of a lowering of symmetry in the crystalline state) [25], ranged between 1075 and $1035 \mathrm{~cm}^{-1}$ in almost all nitrate salts. The $\mathrm{N}-\mathrm{O}$ in plane deformation $\left(v_{4}\left(\mathrm{E}^{\prime}\right)\right)$ ranged between 750 and $705 \mathrm{~cm}^{-1}$ for almost all the 
salts. However, there were some exceptions such as palladium nitrate, whose stretching vibration band was noticeably red-shifted down to $1004 \mathrm{~cm}^{-1}$, or, even, there were new extra bands, as displayed in Figure 1. This phenomenon could be explained by the fact that palladium is not so electropositive and thus, their bonds with nitrate have a covalent character, which provide either the unusual shift of the nitrate bands or new bands due to new covalent cation-anion interactions [25]. In addition, a third band due to the antisymmetric stretching vibration of nitrate $\left(v_{3}\left(E^{\prime}\right)\right)$ was observed for some nitrate salts within the range $1400-1280 \mathrm{~cm}^{-1}$, but it had a negligible intensity.

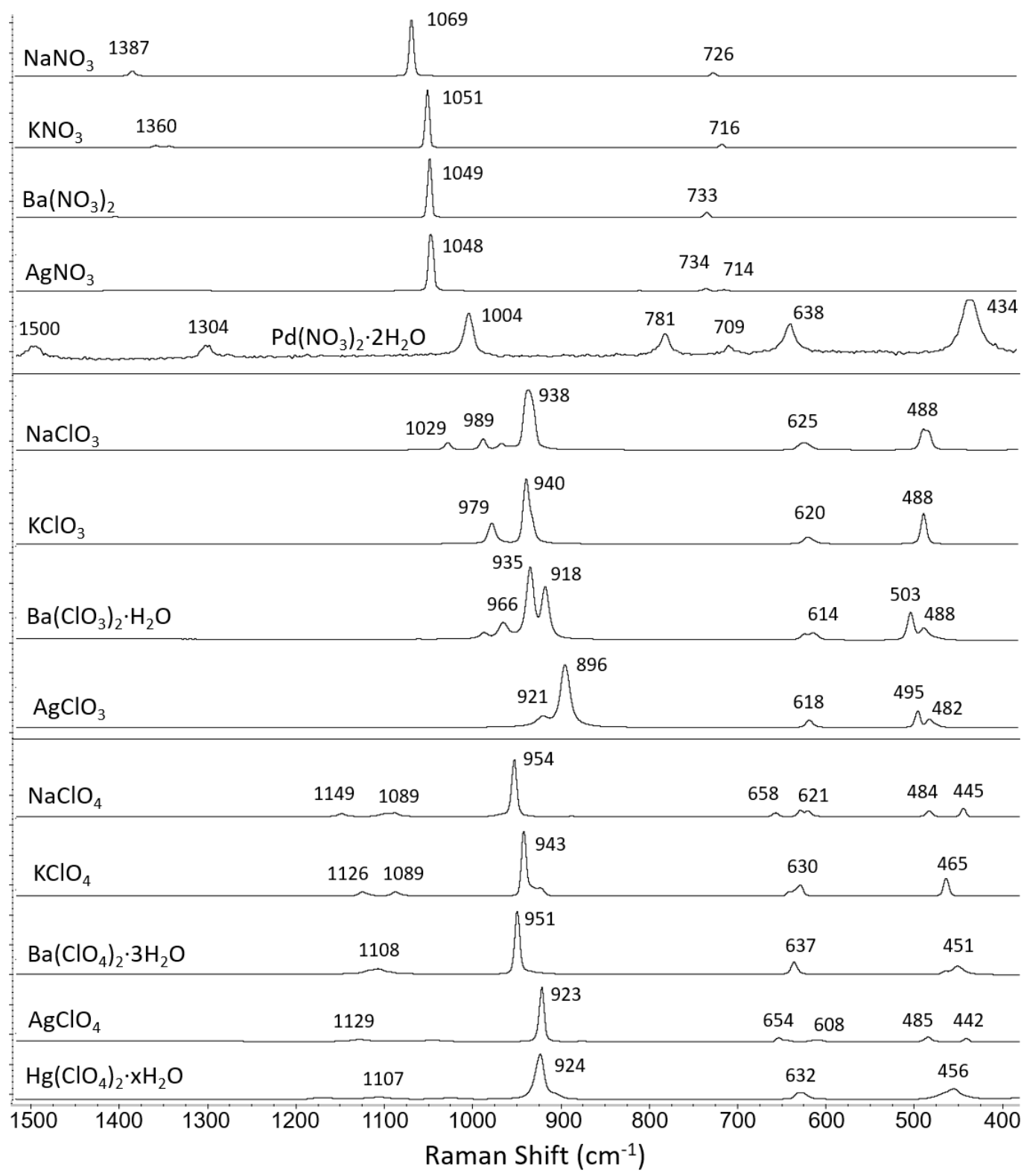

Figure 1. Raman spectra of sodium, potassium, barium, silver and palladium nitrates; sodium, potassium, barium and silver chlorates; and sodium, potassium, barium, silver and mercury perchlorates. Each spectrum is the average of five replicates of the salt, and each replicate was collected using 6 scans of 5 s per scan. 
Regarding chlorate salts, their Raman spectra were characterized by displaying four bands, which resulted from the symmetric and antisymmetric stretching of $\mathrm{Cl}-\mathrm{O}$ and the symmetric and anti-symmetric deformation of $\mathrm{Cl}-\mathrm{O}$. The anti-symmetric $\mathrm{Cl}-\mathrm{O}$ stretching $\left(v_{3}(E)\right)$ ranged from 980 to $960 \mathrm{~cm}^{-1}$ whereas the symmetric $\mathrm{Cl}-\mathrm{O}$ stretching $\left(v_{1}\left(\mathrm{~A}_{1}\right)\right)$ ranged from 940 to $910 \mathrm{~cm}^{-1}$, except for silver chlorate whose anti-symmetric and symmetric stretching vibrations were located at 921 and $896 \mathrm{~cm}^{-1}$, respectively. This shift to smaller wavenumbers might be due to an increase in the covalent character of the bond silver-chlorate, as previously observed for palladium nitrate. The symmetric $\mathrm{Cl}-\mathrm{O}$ deformation $\left(v_{2}\left(A_{1}\right)\right)$ ranged from 630 to $610 \mathrm{~cm}^{-1}$ whereas the anti-symmetric $\mathrm{Cl}-\mathrm{O}$ deformation $\left(v_{4}(E)\right)$ ranged from 500 to $480 \mathrm{~cm}^{-1}$, for all the salts. The Raman spectra of chlorate salts are displayed in Figure 1.

Finally, the Raman spectra of perchlorate salts displayed three main bands, the symmetric stretching of $\mathrm{Cl}-\mathrm{O}$ and two deformations of $\mathrm{Cl}-\mathrm{O}$. The symmetric $\mathrm{Cl}-\mathrm{O}$ stretching $\left(v_{1}\right.$ $\left(A_{1}\right)$ ) ranged from 950 to $930 \mathrm{~cm}^{-1}$, except for silver perchlorate and mercury perchlorate (II) whose bands were located at 923 and $924 \mathrm{~cm}^{-1}$, respectively. Again, a red-shift was observed for the less electropositive metals. The $\mathrm{Cl}-\mathrm{O}$ deformation $\left(v_{4}\left(\mathrm{~T}_{2}\right)\right)$ ranged from 635 to $625 \mathrm{~cm}^{-1}$ whereas the $\mathrm{Cl}-\mathrm{O}$ deformation ( $\left.v_{2}(\mathrm{E})\right)$ ranged from 470 to $445 \mathrm{~cm}^{-1}$, for all the salts except silver perchlorate, as shown in Figure 1. In addition, a fourth band due to the anti-symmetric stretching vibration of perchlorate $\left(v_{3}\left(T_{2}\right)\right)$ was observed for most perchlorate salts within the range $1150-1040 \mathrm{~cm}^{-1}$, but it had a negligible intensity.

The characteristic Raman spectra of every salt are displayed in Supplementary Figure 1 (Annexe1).

\subsection{Discrimination of Energetic Salts Using IR Spectroscopy}

As occurred with Raman, the IR spectra of these oxidizing salts were also dominated by those bands due to the vibrational modes of the anion.

However, contrary to Raman, nitrate salts displayed four characteristic bands in their IR spectra, which were due to the four vibrational modes of the nitrate molecule. Instead of the symmetric stretching vibration of nitrate $\left(v_{1}\left(\mathrm{~A}_{1}{ }_{1}\right)\right)$, which appeared as a unique sharp medium-intense band or two sharp little-intense separate bands, within the range 1060 and $1020 \mathrm{~cm}^{-1}$; the most intense band in the IR spectra was a wide band from1450 to 1270 $\mathrm{cm}^{-1}$ which was due to the antisymmetric stretching vibration $\left(v_{3}\left(E^{\prime}\right)\right)$. For many salts 
such as barium, nickel, copper or gadolinium, this unique wide band split into two or three bands. It should be highlighted that, theoretically, the symmetric stretching vibration of nitrate $\left(v_{1}\left(A^{\prime} 1\right)\right)$ is not IR active. However, it was observed in the IR spectra for most nitrate salts. This fact might be explained by a lowering of symmetry in the crystalline state [25]. Finally, the IR spectra of nitrate salts also displayed those bands due to the out-of-plane and in-plane deformation vibrational modes. The out-of-plane deformation band $\left(v_{2}\left(A^{\prime \prime}{ }_{2}\right)\right)$ ranged from 840 to $800 \mathrm{~cm}^{-1}$, whereas the in-plane deformation band $\left(v_{4}\left(E^{\prime}\right)\right)$ was located within the range $780-700 \mathrm{~cm}^{-1}$. The unique exception was palladium nitrate, whose bands were located at 899 and $784 \mathrm{~cm}^{-1}$, as shown in Figure 2. Unexpectedly, in this case, the shift occurred towards higher wavenumbers.

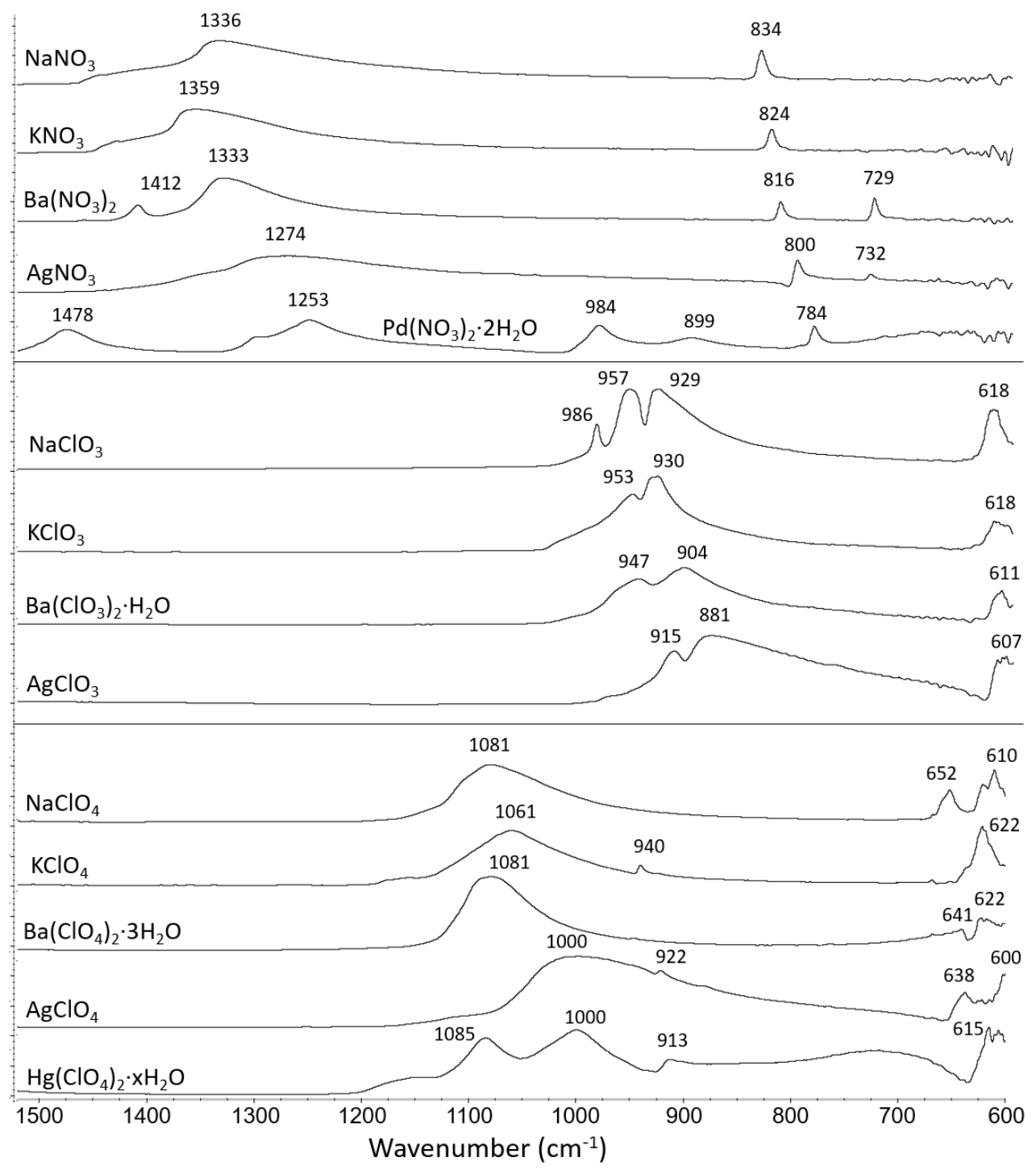

Figure 2. ATR-FTIR spectra of sodium, potassium, barium, silver and palladium nitrates; sodium, potassium, barium and silver chlorates; and sodium, potassium, barium, silver and mercury perchlorates. Each spectrum is the average of five replicates of the salt, and each replicate was collected using 16 scans. 
Regarding the chlorate salts, their IR spectra displayed three main bands due to the vibrational modes of the chlorate. The antisymmetric $\mathrm{Cl}-\mathrm{O}$ stretching $\left(v_{3}(\mathrm{E})\right)$ ranged from 990 to $950 \mathrm{~cm}^{-1}$ whereas the symmetric $\mathrm{Cl}-\mathrm{O}$ stretching $\left(v_{1}\left(\mathrm{~A}_{1}\right)\right)$ ranged from 930 to $900 \mathrm{~cm}^{-1}$, except for silver chlorate whose anti-symmetric and symmetric stretching vibrations were located at 915 and $881 \mathrm{~cm}^{-1}$, respectively. As previously mentioned, this shift to smaller wavenumbers might be due to an increase in the covalent character of the bond silver-chlorate. Finally, the symmetric $\mathrm{Cl}-\mathrm{O}$ deformation $\left(v_{2}\left(\mathrm{~A}_{1}\right)\right)$ ranged from 630 to $610 \mathrm{~cm}^{-1}$ for all the chlorate salts. Unfortunately, since the IR spectrometer used only covered from 4000 to $600 \mathrm{~cm}^{-1}$, the band due to the anti-symmetric deformation of chlorate $\left(v_{4}(E)\right)$ was not observed. The IR spectra of chlorate salts are displayed in Figure 2.

Likewise, the IR spectra of perchlorate salts displayed three bands from the vibrational modes of perchlorate. The anti-symmetric stretching vibrational mode of perchlorate $\left(v_{3}\right.$ $\left(\mathrm{T}_{2}\right)$ ) displayed a wide intense band that ranged from 1080 to $1030 \mathrm{~cm}^{-1}$, except for silver and mercury perchlorates whose bands were located at $1000 \mathrm{~cm}^{-1}$, as shown in Figure 2. The symmetric stretching of perchlorate $\left(v_{1}\left(A_{1}\right)\right)$ was only observed in half of the salts as a little-intense band that ranged from 950 to $930 \mathrm{~cm}^{-1}$; which could be explained by the fact that, theoretically, the symmetric stretching of perchlorate is not IR active. Finally, the perchlorate deformation $\left(v_{4}\left(T_{2}\right)\right)$ ranged from 630 to $600 \mathrm{~cm}^{-1}$. Unfortunately, as previously explained for one of the chlorate deformations, the perchlorate deformation $\left(v_{2}(E)\right)$ was not observed because of being located below the range measured by the IR spectrometer used.

The characteristic IR spectra of every salt are displayed in Supplementary Figure 2 (Annexe 2).

\subsection{The Spectral Influence of Water in Hydrated Salts}

As evidenced in experimental section, most of the salts were hydrated. Thus, the influence of water was studied by comparing the spectra of the same salt when hydrated and nonhydrated. Particularly, commercial anhydrous sodium perchlorate was compared with commercial sodium perchlorate monohydrate. As expected, spectra of both salts (either Raman or IR) were quite similar. Both displayed the main bands from the vibrational modes of the perchlorate and the respective shift influenced by the sodium. Nevertheless, 
despite the evident similarities, there were also significant differences. Regarding IR spectroscopy, the most noticeable change was the presence of the band from water at $1627 \mathrm{~cm}^{-1}$ (water is IR active). Fortunately, this change was removed when considering only the IR range of nitrates, chlorates and perchlorates vibrations (from 600 to 1500 $\mathrm{cm}^{-1}$ ). Also noticeable was the presence of a new band at $652 \mathrm{~cm}^{-1}$ in the anhydrous salt in contrast to the hydrated one. This fact was also verified by Raman $\left(658 \mathrm{~cm}^{-1}\right)$. In addition, when comparing their Raman spectra, the most noticeable change was the fact that those bands due to deformation vibrational modes in sodium perchlorate monohydrate split into two bands in anhydrous sodium perchlorate, as displayed in Figure 3.

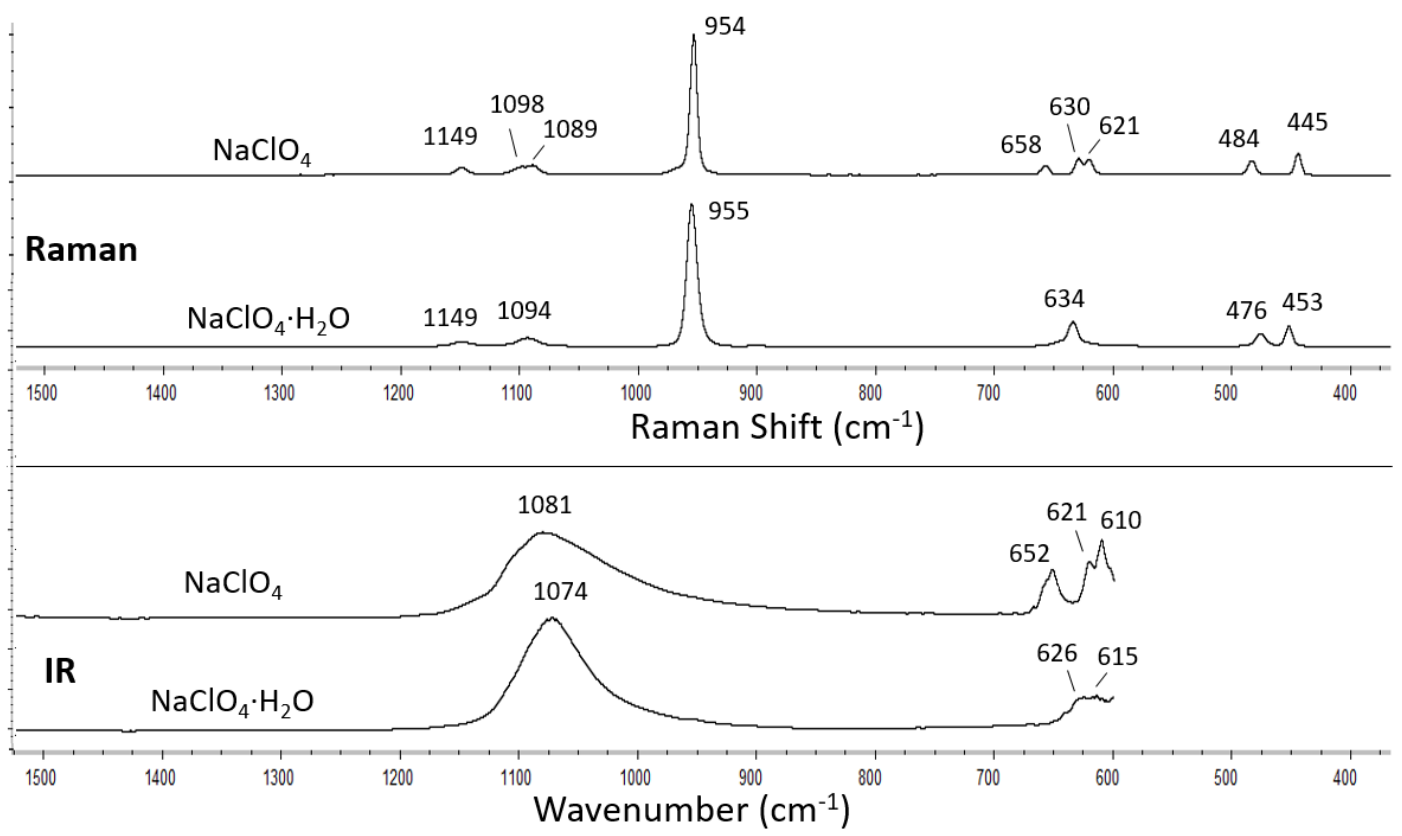

Figure 3. Raman and ATR-FTIR spectra of sodium perchlorate anhydrous and hydrate.

Thus, the presence of this new band located at $658 \mathrm{~cm}^{-1}$ in the anhydrous salt and the two bands at 630 and $621 \mathrm{~cm}^{-1}$ in Raman is likely explained by the splitting of the tridegenerate deformation $\left(v_{4}\left(T_{2}\right)\right)$ because of a significant lowering of the symmetry in the anhydrous salt. In fact, the presence of water molecules within the ionic crystalline structure seems to unify those small shifts of vibrational modes of the anion that are due to the lowering of symmetry in the crystalline state. This effect, observed for sodium perchlorate monohydrate, also occurred in other di-, tri- and tetra-hydrate salts. This fact seems to evidence that the presence of water (either mono-, di-, tri-hydrate, etc.) reduces the splitting of bands keeping the degeneration of the vibrational mode in contrast to 
anhydrous salts. Most nitrate, chlorate and perchlorate salts are highly hygroscopic. Thus, it is expected that they will contain some level of hydration in real samples. Therefore, this aspect should be taken into account when identifying the salts.

\subsection{Statistical Discrimination of Energetic Salts Using Pearson Correlation}

Positively, by studying either the Raman or IR spectra of an unknown oxidizing salt, the main bands in the spectra easily reveal the nature of the anion, i.e. nitrate, chlorate or perchlorate. To this aim, Table 1 summarizes the experimental Raman and IR ranges within which the vibrational modes of nitrates, chlorates and perchlorates appeared.

Table 1. Vibrational modes of nitrates, chlorates and perchlorates [25-27] and the experimental Raman and IR ranges within which were located in this study.

\begin{tabular}{|c|c|c|c|c|c|c|c|c|}
\hline \multirow{4}{*}{ Nitrates } & \multicolumn{2}{|c|}{$v_{1}\left(A^{\prime}{ }_{1}\right)$} & \multicolumn{2}{|c|}{$v_{2}\left(A^{\prime \prime}{ }^{\prime}\right)$} & \multicolumn{2}{|c|}{$v_{3}\left(E^{\prime}\right)$} & \multicolumn{2}{|c|}{$v_{4}\left(E^{\prime}\right)$} \\
\hline & \multicolumn{2}{|c|}{$\begin{array}{l}\text { Symmetric stretch } \\
\text { (Raman active) }\end{array}$} & \multicolumn{2}{|c|}{$\begin{array}{l}\text { Out of plane } \\
\text { deformation (IR } \\
\text { active) }\end{array}$} & \multicolumn{2}{|c|}{$\begin{array}{l}\text { Anti-symmetric stretch } \\
\text { (Raman-IR active) }\end{array}$} & \multicolumn{2}{|c|}{$\begin{array}{l}\text { In plane deformation } \\
\text { (Raman-IR active) }\end{array}$} \\
\hline & Raman & $\mathrm{IR}^{1}$ & \multicolumn{2}{|c|}{ IR } & Raman $^{2}$ & IR & Raman & IR \\
\hline & $1075-1035$ & $1060-1020$ & \multicolumn{2}{|c|}{$840-800$} & $1400-1280$ & $1450-1270$ & $750-705$ & $780-700$ \\
\hline \multirow{4}{*}{ Chlorates } & \multicolumn{2}{|c|}{$v_{1}\left(A_{1}\right)$} & \multicolumn{2}{|c|}{$v_{2}\left(A_{1}\right)$} & \multicolumn{2}{|c|}{$v_{3}(E)$} & \multicolumn{2}{|c|}{$v_{4}(E)$} \\
\hline & \multicolumn{2}{|c|}{$\begin{array}{l}\text { Symmetric stretch } \\
\text { (Raman-IR active) }\end{array}$} & \multicolumn{2}{|c|}{$\begin{array}{c}\text { Symmetric } \\
\text { deformation } \\
\text { (Raman-IR active) } \\
\end{array}$} & \multicolumn{2}{|c|}{$\begin{array}{l}\text { Anti-symmetric stretch } \\
\text { (Raman-IR active) }\end{array}$} & \multicolumn{2}{|c|}{$\begin{array}{l}\text { Anti-symmetric } \\
\text { deformation } \\
\text { (Raman-IR active) } \\
\end{array}$} \\
\hline & Raman & IR & Raman & IR & Raman & IR & Raman & $\mathrm{IR}^{2}$ \\
\hline & $940-910$ & $930-900$ & \multicolumn{2}{|c|}{$630-610$} & $980-960$ & $990-950$ & $500-480$ & - \\
\hline \multirow{4}{*}{ Perchlorates } & \multicolumn{2}{|c|}{$v_{1}\left(A_{1}\right)$} & \multicolumn{2}{|c|}{$v_{2}(E)$} & \multicolumn{2}{|c|}{$v_{3}\left(T_{2}\right)$} & \multicolumn{2}{|c|}{$v_{4}\left(T_{2}\right)$} \\
\hline & \multicolumn{2}{|c|}{$\begin{array}{c}\text { Symmetric stretch } \\
\text { (Raman active) }\end{array}$} & \multicolumn{2}{|c|}{$\begin{array}{c}\text { Deformation } \\
\text { (Raman active) } \\
\end{array}$} & \multicolumn{2}{|c|}{$\begin{array}{c}\text { Anti-symmetric stretch } \\
\text { (Raman-IR active) }\end{array}$} & \multicolumn{2}{|c|}{$\begin{array}{c}\text { Deformation } \\
\text { (Raman-IR active) } \\
\end{array}$} \\
\hline & Raman & $\mathrm{IR}^{1}$ & Raman & $\mathrm{IR}^{1,2}$ & Raman & IR & Raman & IR \\
\hline & $950-930$ & $950-930$ & $470-445$ & - & $1150-1040$ & $1080-1030$ & $635-625$ & $630-600$ \\
\hline \multicolumn{9}{|c|}{$\begin{array}{l}\text { IR }^{1} \text { : Theoretical IR inactive vibrations violated by the lowering of symmetry in the crystalline state. } \\
\text { IR }^{2} \text { : Bands below the IR range considered in this work. } \\
\text { Raman }^{2} \text { : Negligible-intense bands. }\end{array}$} \\
\hline
\end{tabular}

Negatively, the determination of the cation was not so straightforward. No spectral bands came from the cation except for molecular cations as ammonium. However, it was evidenced, for either Raman or IR, that the vibrational modes from the anion were influenced somehow by the cation. A noticeable shift in their Raman shift/wavenumber was observed depending on the cation to which the anion was bonded. Since it is widely known that IR and Raman spectroscopy are complementary techniques; in this study, the capability of both Raman and IR spectral features to unequivocally identify each 
oxidizing salt was examined, as well as the identification improvement when combining both techniques.

In order to mathematically evaluate the unequivocal identification, i.e. whether the spectral differences among salts enable their discrimination; the Pearson correlation coefficients ( $r$ ) were calculated and studied. To this aim, the $r$ between spectra of the same salt (intra-correlation) was compared with the $r$ between spectra of different salts (intercorrelation). A Pearson value over 0.95 was selected as the condition to confirm the identification.

Positively, the intra-correlation using only Raman was over 0.95 for all the salts except for $\mathrm{Hg}\left(\mathrm{ClO}_{4}\right)_{2}, \mathrm{Mg}\left(\mathrm{ClO}_{4}\right)_{2}, \mathrm{Co}\left(\mathrm{NO}_{3}\right)_{2}, \mathrm{Lu}\left(\mathrm{NO}_{3}\right)_{3}$ and $\mathrm{Y}\left(\mathrm{NO}_{3}\right)_{3}$, whose average $\mathrm{r}$ values were $0.91,0.84,0.90,0.92$ and 0.87 , respectively. Afterwards, the inter-variability between salts was evaluated. Interestingly, 25 salts were unequivocally identified using Raman as summarized in Table 2, i.e. their intra-variability was lower than their intervariability since their intra-correlation was over 0.95 (except for $\mathrm{Hg}\left(\mathrm{ClO}_{4}\right)_{2}$ and $\mathrm{Lu}\left(\mathrm{NO}_{3}\right)_{3}$ ) while their inter-correlation with any other salt was below 0.95 (or 0.90 in the case of $\mathrm{Hg}\left(\mathrm{ClO}_{4}\right)_{2}$ and $\left.\mathrm{Lu}\left(\mathrm{NO}_{3}\right)_{3}\right)_{\text {. }}$.

Table 2. Unequivocally identified salts by comparing through Pearson correlation their Raman spectra, IR spectra or both. Intra-correlation was over 0.95 while inter-correlation with any other salt was below 0.95 . In order to save space, only the chemical formula of the salt (cation-anion) is displayed, not the number of hydrated water molecules.

\begin{tabular}{|c|c|c|}
\hline \multicolumn{3}{|c|}{$\begin{array}{c}\text { Unequivocally Identified Salts } \\
\text { (Intra-variability < Inter-variability) }\end{array}$} \\
\hline Raman (25/72) & IR (30/72) & Raman + IR (44/72) \\
\hline $\begin{array}{c}\mathrm{AgClO} \\
\mathrm{NaClO}_{3}, \mathrm{Ba}\left(\mathrm{ClO}_{3}\right)_{2}, \mathrm{KClO}_{3}, \mathrm{Ba}\left(\mathrm{ClO}_{4}\right)_{2}, \\
\mathrm{Hg}\left(\mathrm{ClO}_{4}\right)_{2} *, \mathrm{KClO}_{4}, \mathrm{NaClO}_{4}, \\
\left(\mathrm{NH}_{4}\right)_{2} \mathrm{Ce}\left(\mathrm{NO}_{3}\right)_{6}, \mathrm{Bi}\left(\mathrm{NO}_{3}\right)_{3}, \\
\mathrm{Cr}\left(\mathrm{NO}_{3}\right)_{3}, \mathrm{Cu}\left(\mathrm{NO}_{3}\right)_{2}, \\
\mathrm{Er}\left(\mathrm{NO}_{3}\right)_{3}, \mathrm{Eu}\left(\mathrm{NO}_{3}\right)_{3}, \\
\mathrm{Hg}\left(\mathrm{NO}_{3}\right)_{2}, \mathrm{LiNO}_{3}, \\
\mathrm{Lu}\left(\mathrm{NO}_{3}\right)_{3}, \mathrm{Mg}\left(\mathrm{NO}_{3}\right)_{2}, \\
\mathrm{NaNO}_{3}, \mathrm{Pd}\left(\mathrm{NO}_{3}\right)_{2}, \mathrm{Sc}_{\left(\mathrm{NO}_{3}\right)_{3},} \\
\mathrm{Sm}\left(\mathrm{NO}_{3}\right)_{3}, \mathrm{Tl}_{\left(\mathrm{NO}_{3}\right)_{3} \&} \\
\mathrm{TlNO}_{3}\end{array}$ & 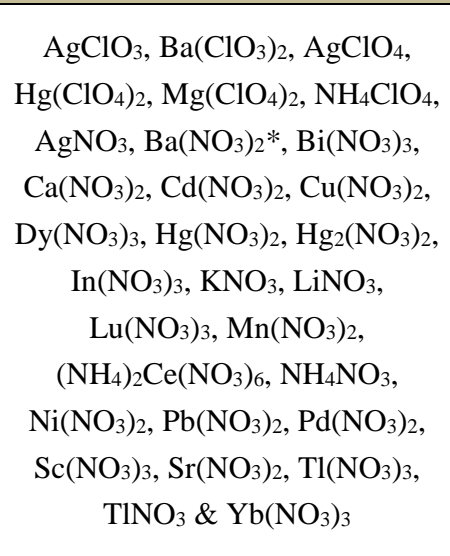 & 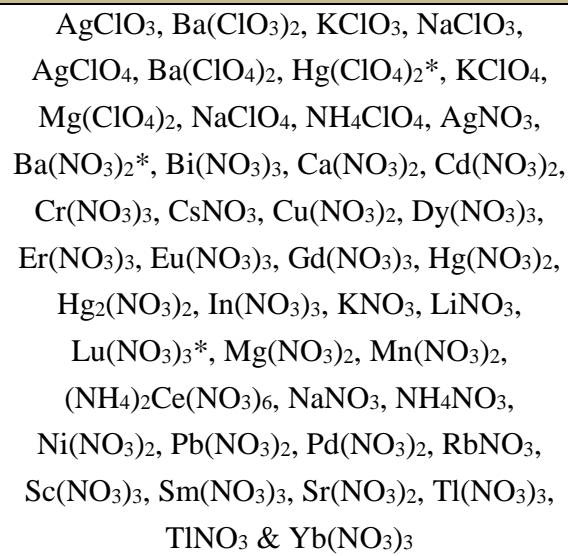 \\
\hline
\end{tabular}


Likewise, the intra-correlation using IR was over 0.95 for all the salts except for $\mathrm{Fe}\left(\mathrm{ClO}_{4}\right)_{3}, \mathrm{Ni}\left(\mathrm{ClO}_{4}\right)_{2}, \mathrm{Ba}\left(\mathrm{NO}_{3}\right)_{2}, \mathrm{Er}\left(\mathrm{NO}_{3}\right)_{3}, \mathrm{Ga}\left(\mathrm{NO}_{3}\right)_{3}, \mathrm{Nd}\left(\mathrm{NO}_{3}\right)_{3}, \mathrm{Tm}\left(\mathrm{NO}_{3}\right)_{3}$ and $\mathrm{Y}\left(\mathrm{NO}_{3}\right)_{3}$, whose average $\mathrm{r}$ values were $0.89,0.86,0.94,0.87,0.94,0.94,0.93$ and 0.90 , respectively. After evaluating the inter-variability, 30 salts were unequivocally identified using IR, as summarized in Table 2, i.e. their intra-variability was lower than their intervariability since their intra-correlation was over 0.95 (except for $\mathrm{Ba}\left(\mathrm{NO}_{3}\right)_{2}$ ) while their inter-correlation was below 0.95 (or 0.94 in the case of $\mathrm{Ba}\left(\mathrm{NO}_{3}\right)_{2}$ ).

Finally, it was decided to study the salts which remained undistinguishable by evaluating together Raman and IR spectroscopy. By combining both spectroscopic techniques, there were 44 salts which were unequivocally identified as summarized in Table 2, i.e. their intra-correlation (for both Raman and IR) was over 0.95 while their inter-correlation with any other salt (using either Raman, IR or both) was below 0.95 .

In addition to Table 2, which summarizes the salts that were identified, Table 3 was created to summarize the groups of salts that were undistinguishable among each other. For those non-identified salts, it was useful to study the correlation among them and check which ones were undistinguishable and might be erroneously mistaken. Regarding Raman spectroscopy, there were 26 groups of salts with an average of 3 salts per group which were undistinguishable among each other. However, it was noticeable that groups of perchlorate salts contained a larger number of undistinguishable salts (up to 10) than nitrate groups (in which the number of undistinguishable salts ranged from 2 to 4). Concerning IR, there were 23 groups of salts with an average of 3 salts per group which were undistinguishable among each other. In this case, both perchlorate and nitrate groups contained a similar number of undistinguishable salts (from 2 to 5). Finally, when considering together Raman and IR, there were still 15 groups of salts with an average of 3 salts per group (for perchlorate groups) and 2 salts per group (for nitrate groups) which were undistinguishable among each other.

By studying the Raman and IR spectroscopic data of each salt, some of the salts that were not discriminated using either only Raman or IR, were properly discriminated when considering the other technique. For instance, barium nitrate might be erroneously identified as gadolinium or lead nitrate using Raman but it was unequivocally identified using IR. On the contrary, potassium perchlorate might be erroneously identified as nickel perchlorate using IR but it was unequivocally identified using Raman. Furthermore, there 
were some peculiar cases such as caesium nitrate which might be erroneously identified as either calcium, mercury (I) or potassium nitrates using Raman, but as sodium or rubidium nitrates using IR. Positively, by considering both techniques, caesium nitrate was unequivocally identified since no other salt provided a Pearson value over 0.95 for both Raman and IR when compared with caesium nitrate.

Table 3. Groups of undistinguishable salts by comparing through Pearson correlation their Raman spectra, IR spectra or both. Inter-correlation between salts within the same group was over 0.95. In order to save space, only the chemical formula of the salt (cation-anion) is displayed, not the number of hydrated water molecules.

\begin{tabular}{|c|c|c|}
\hline \multicolumn{3}{|c|}{ Groups of undistinguishable Salts } \\
\hline Raman (47/72) & IR (42/72) & Raman + IR (28/72) \\
\hline $\mathrm{Al}\left(\mathrm{ClO}_{4}\right)_{3}, \mathrm{Cd}\left(\mathrm{ClO}_{4}\right)_{2}, \mathrm{Cu}\left(\mathrm{ClO}_{4}\right)_{2} \& \mathrm{Fe}\left(\mathrm{ClO}_{4}\right)_{3}$ & $\mathrm{KClO}_{3} \& \mathrm{NaClO}_{3}$ & $\mathrm{Al}\left(\mathrm{ClO}_{4}\right)_{3} \& \mathrm{Fe}\left(\mathrm{ClO}_{4}\right)_{3}$ \\
\hline $\mathrm{Al}\left(\mathrm{ClO}_{4}\right)_{3}, \mathrm{Cd}\left(\mathrm{ClO}_{4}\right)_{2}, \mathrm{Cu}\left(\mathrm{ClO}_{4}\right)_{2} \& \mathrm{Mg}\left(\mathrm{ClO}_{4}\right)_{2}$ & $\mathrm{Al}\left(\mathrm{ClO}_{4}\right)_{3} \& \mathrm{Fe}\left(\mathrm{ClO}_{4}\right)_{3}$ & $\mathrm{Ca}\left(\mathrm{ClO}_{4}\right)_{2} \& \mathrm{NaClO}_{4} \mathrm{H}_{2} \mathrm{O}$ \\
\hline $\mathrm{Ca}\left(\mathrm{ClO}_{4}\right)_{2}, \mathrm{NaClO}_{4} \mathrm{H}_{2} \mathrm{O} \& \mathrm{Sr}\left(\mathrm{ClO}_{4}\right)_{2}$ & $\mathrm{Ba}\left(\mathrm{ClO}_{4}\right)_{2}, \mathrm{Ca}\left(\mathrm{ClO}_{4}\right)_{2} \& \mathrm{NaClO}_{4}$ & $\mathrm{Ca}\left(\mathrm{ClO}_{4}\right)_{2} \& \mathrm{Sr}\left(\mathrm{ClO}_{4}\right)_{2}$ \\
\hline $\begin{array}{c}\mathrm{Cd}\left(\mathrm{ClO}_{4}\right)_{2}, \mathrm{Ce}\left(\mathrm{ClO}_{4}\right)_{3}, \mathrm{Co}\left(\mathrm{ClO}_{4}\right)_{2}, \mathrm{Fe}\left(\mathrm{ClO}_{4}\right)_{2}, \mathrm{LiClO}_{4} \\
\mathrm{Mg}\left(\mathrm{ClO}_{4}\right)_{2}, \mathrm{Mn}\left(\mathrm{ClO}_{4}\right)_{2}, \mathrm{Ni}\left(\mathrm{ClO}_{4}\right)_{2}, \mathrm{~Pb}\left(\mathrm{ClO}_{4}\right)_{2} \& \\
\mathrm{Zn}\left(\mathrm{ClO}_{4}\right)_{2}\end{array}$ & $\begin{array}{l}\mathrm{Ba}\left(\mathrm{ClO}_{4}\right)_{2}, \mathrm{Ca}\left(\mathrm{ClO}_{4}\right)_{2} \& \\
\mathrm{NaClO}_{4} \mathrm{H}_{2} \mathrm{O}\end{array}$ & $\begin{array}{l}\mathrm{Cd}\left(\mathrm{ClO}_{4}\right)_{2}, \mathrm{Ce}\left(\mathrm{ClO}_{4}\right)_{3} \\
\mathrm{Co}\left(\mathrm{ClO}_{4}\right)_{2} \& \mathrm{Ni}\left(\mathrm{ClO}_{4}\right)_{2}\end{array}$ \\
\hline $\begin{array}{c}\mathrm{Cd}\left(\mathrm{ClO}_{4}\right)_{2}, \mathrm{Co}\left(\mathrm{ClO}_{4}\right)_{2}, \mathrm{Cu}\left(\mathrm{ClO}_{4}\right)_{2}, \mathrm{Mg}\left(\mathrm{ClO}_{4}\right)_{2} \\
\mathrm{Ni}\left(\mathrm{ClO}_{4}\right)_{2} \& \mathrm{Zn}\left(\mathrm{ClO}_{4}\right)_{2}\end{array}$ & $\begin{array}{c}\mathrm{Ca}\left(\mathrm{ClO}_{4}\right)_{2}, \mathrm{Mn}\left(\mathrm{ClO}_{4}\right)_{2} \& \\
\operatorname{Sr}\left(\mathrm{ClO}_{4}\right)_{2}\end{array}$ & $\begin{array}{c}\mathrm{Cd}\left(\mathrm{ClO}_{4}\right)_{2}, \mathrm{Co}\left(\mathrm{ClO}_{4}\right)_{2} \\
\mathrm{Cu}\left(\mathrm{ClO}_{4}\right)_{2}, \mathrm{Ni}\left(\mathrm{ClO}_{4}\right)_{2} \& \\
\mathrm{Zn}\left(\mathrm{ClO}_{4}\right)_{2} \\
\end{array}$ \\
\hline $\begin{array}{c}\mathrm{Cd}\left(\mathrm{ClO}_{4}\right)_{2}, \mathrm{Co}\left(\mathrm{ClO}_{4}\right)_{2}, \mathrm{Fe}\left(\mathrm{ClO}_{4}\right)_{2}, \mathrm{LiClO}_{4}, \mathrm{Mg}\left(\mathrm{ClO}_{4}\right)_{2} \\
\mathrm{Mn}\left(\mathrm{ClO}_{4}\right)_{2}, \mathrm{NH}_{4} \mathrm{ClO}_{4}, \mathrm{Ni}\left(\mathrm{ClO}_{4}\right)_{2} \& \mathrm{Zn}\left(\mathrm{ClO}_{4}\right)_{2}\end{array}$ & $\begin{array}{c}\mathrm{Cd}\left(\mathrm{ClO}_{4}\right)_{2}, \mathrm{Ce}\left(\mathrm{ClO}_{4}\right)_{3}, \mathrm{Co}\left(\mathrm{ClO}_{4}\right)_{2} \\
\& \mathrm{Ni}\left(\mathrm{ClO}_{4}\right)_{2}\end{array}$ & $\begin{array}{l}\mathrm{Cd}\left(\mathrm{ClO}_{4}\right)_{2}, \mathrm{Co}\left(\mathrm{ClO}_{4}\right)_{2} \\
\mathrm{Mn}\left(\mathrm{ClO}_{4}\right)_{2} \& \mathrm{Ni}\left(\mathrm{ClO}_{4}\right)_{2}\end{array}$ \\
\hline $\mathrm{AgNO}_{3}, \mathrm{Mn}\left(\mathrm{NO}_{3}\right)_{2} \& \mathrm{Nd}\left(\mathrm{NO}_{3}\right)_{3}$ & $\begin{array}{c}\mathrm{Cd}\left(\mathrm{ClO}_{4}\right)_{2}, \mathrm{Co}\left(\mathrm{ClO}_{4}\right)_{2}, \mathrm{Cu}\left(\mathrm{ClO}_{4}\right)_{2} \\
\mathrm{Ni}\left(\mathrm{ClO}_{4}\right)_{2} \& \mathrm{Zn}\left(\mathrm{ClO}_{4}\right)_{2}\end{array}$ & $\begin{array}{c}\mathrm{Ce}\left(\mathrm{ClO}_{4}\right)_{3}, \mathrm{LiClO}_{4} \\
\mathrm{Ni}\left(\mathrm{ClO}_{4}\right)_{2} \& \mathrm{~Pb}\left(\mathrm{ClO}_{4}\right)_{2}\end{array}$ \\
\hline $\mathrm{AgNO}_{3} \& \mathrm{~Pb}\left(\mathrm{NO}_{3}\right)_{2}$ & $\begin{array}{c}\mathrm{Cd}\left(\mathrm{ClO}_{4}\right)_{2}, \mathrm{Co}\left(\mathrm{ClO}_{4}\right)_{2}, \mathrm{Mn}\left(\mathrm{ClO}_{4}\right)_{2} \\
\& \mathrm{Ni}\left(\mathrm{ClO}_{4}\right)_{2}\end{array}$ & $\mathrm{Fe}\left(\mathrm{ClO}_{4}\right)_{2} \& \mathrm{Ni}\left(\mathrm{ClO}_{4}\right)_{2}$ \\
\hline $\mathrm{Al}\left(\mathrm{NO}_{3}\right)_{3} \& \mathrm{Ga}\left(\mathrm{NO}_{3}\right)_{3}$ & $\begin{array}{c}\mathrm{Cd}\left(\mathrm{ClO}_{4}\right)_{2}, \mathrm{Mn}\left(\mathrm{ClO}_{4}\right)_{2}, \mathrm{Ni}\left(\mathrm{ClO}_{4}\right)_{2} \\
\& \mathrm{Sr}\left(\mathrm{ClO}_{4}\right)_{2}\end{array}$ & $\mathrm{Al}\left(\mathrm{NO}_{3}\right)_{3} \& \mathrm{Ga}\left(\mathrm{NO}_{3}\right)_{3}$ \\
\hline $\mathrm{Ba}\left(\mathrm{NO}_{3}\right)_{2}, \mathrm{Gd}\left(\mathrm{NO}_{3}\right)_{3} \& \mathrm{~Pb}\left(\mathrm{NO}_{3}\right)_{2}$ & $\begin{array}{c}\mathrm{Ce}\left(\mathrm{ClO}_{4}\right)_{3}, \mathrm{LiClO}_{4}, \mathrm{Ni}\left(\mathrm{ClO}_{4}\right)_{2} \& \\
\mathrm{~Pb}\left(\mathrm{ClO}_{4}\right)_{2} \\
\end{array}$ & $\mathrm{Ce}\left(\mathrm{NO}_{3}\right)_{3} \& \mathrm{La}\left(\mathrm{NO}_{3}\right)_{3}$ \\
\hline $\mathrm{Ca}\left(\mathrm{NO}_{3}\right)_{2} \& \mathrm{Cd}\left(\mathrm{NO}_{3}\right)_{2}$ & $\mathrm{Fe}\left(\mathrm{ClO}_{4}\right)_{2} \& \mathrm{Ni}\left(\mathrm{ClO}_{4}\right)_{2}$ & $\mathrm{Co}\left(\mathrm{NO}_{3}\right)_{2} \& \mathrm{Zn}\left(\mathrm{NO}_{3}\right)_{2}$ \\
\hline $\mathrm{Ca}\left(\mathrm{NO}_{3}\right)_{2}, \mathrm{CsNO}_{3}, \mathrm{Hg}_{2}\left(\mathrm{NO}_{3}\right)_{2} \& \mathrm{KNO}_{3}$ & $\mathrm{KClO}_{4} \& \mathrm{Ni}\left(\mathrm{ClO}_{4}\right)_{2}$ & $\mathrm{Fe}\left(\mathrm{NO}_{3}\right)_{3} \& \mathrm{Ga}\left(\mathrm{NO}_{3}\right)_{3}$ \\
\hline $\mathrm{Ca}\left(\mathrm{NO}_{3}\right)_{2}, \mathrm{Dy}\left(\mathrm{NO}_{3}\right)_{3}, \mathrm{Hg}_{2}\left(\mathrm{NO}_{3}\right)_{2} \& \mathrm{KNO}_{3}$ & $\mathrm{Al}\left(\mathrm{NO}_{3}\right)_{3} \& \mathrm{Ga}\left(\mathrm{NO}_{3}\right)_{3}$ & $\mathrm{Ho}\left(\mathrm{NO}_{3}\right)_{3} \& \mathrm{~Tb}\left(\mathrm{NO}_{3}\right)_{3}$ \\
\hline $\mathrm{Ca}\left(\mathrm{NO}_{3}\right)_{2}, \mathrm{Dy}\left(\mathrm{NO}_{3}\right)_{3}, \mathrm{Hg}_{2}\left(\mathrm{NO}_{3}\right)_{2} \& \mathrm{Y}\left(\mathrm{NO}_{3}\right)_{3}$ & $\mathrm{Ce}\left(\mathrm{NO}_{3}\right)_{3} \& \mathrm{La}\left(\mathrm{NO}_{3}\right)_{3}$ & $\mathrm{Nd}\left(\mathrm{NO}_{3}\right)_{3} \& \operatorname{Pr}\left(\mathrm{NO}_{3}\right)_{3}$ \\
\hline $\mathrm{Ca}\left(\mathrm{NO}_{3}\right)_{2}, \mathrm{Dy}\left(\mathrm{NO}_{3}\right)_{3}, \mathrm{Y}\left(\mathrm{NO}_{3}\right)_{3} \& \mathrm{Yb}\left(\mathrm{NO}_{3}\right)_{3}$ & $\mathrm{Co}\left(\mathrm{NO}_{3}\right)_{2}, \mathrm{Mg}\left(\mathrm{NO}_{3}\right)_{2} \& \mathrm{Zn}\left(\mathrm{NO}_{3}\right)_{2}$ & $\mathrm{Tm}\left(\mathrm{NO}_{3}\right)_{3} \& \mathrm{Y}\left(\mathrm{NO}_{3}\right)_{3}$ \\
\hline $\mathrm{Ce}\left(\mathrm{NO}_{3}\right)_{3}, \mathrm{Fe}\left(\mathrm{NO}_{3}\right)_{3} \& \mathrm{Ga}\left(\mathrm{NO}_{3}\right)_{3}$ & $\mathrm{Cr}\left(\mathrm{NO}_{3}\right)_{3}, \mathrm{Fe}\left(\mathrm{NO}_{3}\right)_{3} \& \mathrm{Ga}\left(\mathrm{NO}_{3}\right)_{3}$ & \\
\hline $\mathrm{Ce}\left(\mathrm{NO}_{3}\right)_{3}, \mathrm{Fe}\left(\mathrm{NO}_{3}\right)_{3} \& \mathrm{La}\left(\mathrm{NO}_{3}\right)_{3}$ & $\mathrm{CsNO}_{3}, \mathrm{NaNO}_{3} \& \mathrm{RbNO}_{3}$ & \\
\hline $\mathrm{Co}\left(\mathrm{NO}_{3}\right)_{2} \& \mathrm{Zn}\left(\mathrm{NO}_{3}\right)_{2}$ & $\begin{array}{c}\mathrm{Er}\left(\mathrm{NO}_{3}\right)_{3}, \mathrm{Ho}\left(\mathrm{NO}_{3}\right)_{3}, \mathrm{~Tb}\left(\mathrm{NO}_{3}\right)_{3} \& \\
\mathrm{Tm}\left(\mathrm{NO}_{3}\right)_{3}\end{array}$ & \\
\hline $\mathrm{Dy}\left(\mathrm{NO}_{3}\right)_{3} \& \mathrm{Gd}\left(\mathrm{NO}_{3}\right)_{3}$ & $\mathrm{Eu}\left(\mathrm{NO}_{3}\right)_{3}, \operatorname{Pr}\left(\mathrm{NO}_{3}\right)_{3} \& \mathrm{Sm}\left(\mathrm{NO}_{3}\right)_{3}$ & \\
\hline $\mathrm{Ho}\left(\mathrm{NO}_{3}\right)_{3} \& \mathrm{~Tb}\left(\mathrm{NO}_{3}\right)_{3}$ & $\mathrm{Gd}\left(\mathrm{NO}_{3}\right)_{3} \& \mathrm{Y}\left(\mathrm{NO}_{3}\right)_{3}$ & \\
\hline $\mathrm{Ho}\left(\mathrm{NO}_{3}\right)_{3} \& \mathrm{Y}\left(\mathrm{NO}_{3}\right)_{3}$ & $\mathrm{Nd}\left(\mathrm{NO}_{3}\right)_{3}, \operatorname{Pr}\left(\mathrm{NO}_{3}\right)_{3} \& \mathrm{Sm}\left(\mathrm{NO}_{3}\right)_{3}$ & \\
\hline $\mathrm{In}\left(\mathrm{NO}_{3}\right)_{3} \& \mathrm{Zn}\left(\mathrm{NO}_{3}\right)_{2}$ & $\mathrm{Sm}\left(\mathrm{NO}_{3}\right)_{3} \& \mathrm{Y}\left(\mathrm{NO}_{3}\right)_{3}$ & \\
\hline $\mathrm{Mn}\left(\mathrm{NO}_{3}\right)_{2}, \mathrm{Nd}\left(\mathrm{NO}_{3}\right)_{3}, \mathrm{NH}_{4} \mathrm{NO}_{3} \& \operatorname{Pr}\left(\mathrm{NO}_{3}\right)_{3}$ & $\mathrm{Tm}\left(\mathrm{NO}_{3}\right)_{3} \& \mathrm{Y}\left(\mathrm{NO}_{3}\right)_{3}$ & \\
\hline \multicolumn{3}{|l|}{$\mathrm{Ni}\left(\mathrm{NO}_{3}\right)_{2} \& \mathrm{Zn}\left(\mathrm{NO}_{3}\right)_{2}$} \\
\hline \multicolumn{3}{|l|}{$\mathrm{RbNO}_{3}, \mathrm{Sr}\left(\mathrm{NO}_{3}\right)_{2} \& \mathrm{Zn}\left(\mathrm{NO}_{3}\right)_{2}$} \\
\hline $\mathrm{Tm}\left(\mathrm{NO}_{3}\right)_{3} \& \mathrm{Y}\left(\mathrm{NO}_{3}\right)_{3}$ & & \\
\hline
\end{tabular}




\section{Conclusions}

Vibrational spectroscopic techniques such as IR and Raman spectroscopy enable an accurate discrimination of oxidizing salts according to their different anions: nitrates, chlorates and perchlorates. The characteristic chemical vibrational modes of these anions are selective enough to identify these salts either using IR or Raman spectroscopy.

Nevertheless, the discrimination between salts that have the same anion and only differ in the cation was not so straightforward. Thus, besides the visual spectra comparison, a simple statistical analysis based on Pearson correlation helps to objectively discriminate and identify these salts, discriminating the cation. According to the results, the cation influences the shift of the bands from the anion.

Some salts, which contained the same anion and different cations, were not unequivocally identified when using only their IR or Raman spectra, but when combining IR and Raman information. In fact, the discrimination of salts significantly improved when considering both techniques together, despite the fact that there were still 28 salts that were not unequivocally identified.

It is important to highlight that spectral ranges considered in this study were dominated by the vibrational modes of the anions (due to their covalent bonds) and their shift due to the cation-anion interactions. However, in order to improve the discrimination, further information involving the lattice modes of these solid crystalline salts might be studied using high resolution instruments covering the spectral range below $400 \mathrm{~cm}^{-1}$.

A further relevant challenge involves the simultaneous identification of different salts in mixtures. It is essential to study whether two salts in a mixture might be spectrally resolved. Depending on how much their main characteristic bands differ among each other, high or medium spectral resolution might be required. Further research to answer this point is highly necessary. 


\section{Acknowledgements}

The authors greatly thankMireya Calvo andMaríaMartínez for their support in the collection of the Raman and IR spectra of samples. Félix Zapata also thanks the Spanish Ministry of Education for his PhD research fellowship FPU014/00790.

\section{References}

[1] A. Beveridge, Forensic Investigation of Explosions, Taylor \& Francis, 1998.

[2] J.B. Ledgard, The preparation of nitrates, chlorates, and perchlorates, in: J.B. Ledgard (Ed.), The Preparatory Manual of Explosives, Paranoid Publications, 2002.

[3] J.T. Thurman, Practical Bomb Scene Investigation, Taylor \& Francis, 2006.

[4] TM 31-210, Improvised Munitions Handbook (Improvised Explosive Devices or IEDs), Department of the Army Technical Manual, 2007.

[5] J. Donner, A Professional's Guide to Pyrotechnics: Understanding and Making Exploding Fireworks, Paladin Press, 1997.

[6] J.B. Ledgard, The Preparatory Manual of Black Powder and Pyrotechnics, Lulu, 2006.

[7] R. Meyer, J. Köhler, A. Homburg, Explosives, Sixth edition Wiley, 2007.

[8] M. Pumera, Analysis of explosives via microchip electrophoresis and conventional capillary electrophoresis: a review, Electrophoresis 27 (2006) 244256.

[9] K.G. Hopper, H. LeClair, B.R. McCord, A novel method for analysis of explosives residue by simultaneous detection of anions and cations via capillary zone electrophoresis, Talanta 67 (2005) 304-312.

[10] J.P. Hutchinson, C.J. Evenhuis, C. Johns, A.A. Kazarian, M.C. Breadmore, M. Macka, E.F. Hilder, R.M. Guijt, G.W. Dicinoski, P.R. Haddad, Identification of inorganic improvised explosive devices by analysis of post-blast residues using portable capillary electrophoresis instrumentation and indirect photometric detection with a light emitting diode, Anal. Chem. 79 (2007) 70057013.

[11] J.P. Hutchinson, C. Johns, M.C. Breadmore, E.F. Hilder, R.M. Guijt, C. Lennard, G. Dicinoski, P.R. Haddad, Identification of inorganic ions in post-blast 
explosive residues using portable $\mathrm{CE}$ instrumentation and capacitively coupled contactless conductivity detection, Electrophoresis 29 (2008) 4593-4602. C. Sarazin, N. Delaunay, A. Varenne, J. Vial, C. Costanza, V. Eudes, J. Minet, P. Gareil, Identification and determination of inorganic anions in real extracts from pre- and post-blast residues by capillary electrophoresis, J. Chromatogr. A 1217 (2010) 6971-6978.

[13] C. Martín-Alberca, M.A. Fernández de la Ossa, J. Sáiz, J.L. Ferrando, C. García-Ruiz, Anions in pre- and post-blast consumer fireworks by capillary electrophoresis, Electrophoresis 35 (2014) 3272-3280.

[14] D.K. Kuila, A. Chakrabortty, S.P. Sharma, S.C. Lahiri, Composition profile of low explosives from cases in India, Forensic Sci. Int. 159 (2006) 127131.

[15] G.W. Dicinoski, R.A. Shellie, P.R. Haddad, Forensic identification of inorganic explosives by ion chromatography, Anal. Lett. 39 (4) (2006) 639-657.

[16] C. Johns, R.A. Shellie, O.G. Potter, J.W. O'Reilly, J.P. Hutchinson, R.M. Guijt, M.C. Breadmore, E.F. Hilder, G.W. Dicinoski, P.R. Haddad, Identification of homemade inorganic explosives by ion chromatography analysis of post-blast residues, J. Chromatogr. A 1182 (2008) 205-214.

[17] E. Tyrrell, E.F. Hilder, R.A. Shalliker, G.W. Dicinoski, R.A. Shellie, M.C. Breadmore, C.A. Pohl, P.R. Haddad, Packing procedures for high efficiency, short ion-exchange columns for rapid separation of inorganic anions, J. Chromatogr. A 1208 (2008) 95-100.

[18] H. Meng, T. Wang, B. Guo, Y. Hashi, C. Guo, J. Lin, Simultaneous determination of inorganic anions and cations in explosive residues by ion chromatography, Talanta 76 (2008) 241-245.

[19] L. Barron, E. Gilchrist, Ion chromatography-mass spectrometry: a review of recent technologies and application in forensic and environmental explosives analysis, Anal. Chim. Acta 806 (2014) 27-54.

[20] C. Martín-Alberca, F. Zapata, H. Carrascosa, F.E. Ortega-Ojeda, C. García-Ruiz, Study of consumer fireworks post-blast residues by ATR-FTIR, Talanta 149 (2016) 257-265.

[21] F. Zapata, M.A. Fernández de la Ossa, E. Gilchrist, L. Barron, C. GarcíaRuiz, Progressing the analysis of improvised explosive devices: comparative 
study for trace detection of explosive residues in handprints by Raman spectroscopy and liquid chromatography, Talanta 161 (2016) 219-227.

[22] M.R. Almeida, D.N. Correa, J.J. Zacca, L.P.L. Logrado, R.J. Poppi, Detection of explosives on the surface of banknotes by Raman hyperspectral imaging and independent component analysis, Anal. Chim. Acta 860 (2015) 1522.

[23] F. Zapata, C. García-Ruiz, Determination of nanogram microparticles from explosives after real open-air explosions by confocal Raman microscopy, Anal. Chem. 88 (2016) 6726-6733.

[24] F. Zapata, C. García-Ruiz, Analysis of different materials subjected to open-air explosions in search of explosive traces by Raman microscopy, Forensic Sci. Int. 275 (2017) 57-64.

[25] R.A. Nyquist, R.O. Kagel, Handbook of Infrared and Raman Spectra of Inorganic Compounds and Organic Salts. Chapter 1, Infrared Spectra of Inorganic Compounds, Academic Press, 1971.

[26] K. Nakamoto, Infrared and Raman Spectra of Inorganic and Coordination Compounds, Part A. Theory and Applications in Inorganic Chemistry, 6th edition John Wiley and Sons Inc., New York, 2009.

[27] J.T. Kloprogge, D. Wharton, L. Hickey, R.L. Frost, Infrared and Raman study of interlayer anions $\mathrm{CO}_{3}{ }^{2-}, \mathrm{NO}_{3}{ }^{-}, \mathrm{SO}_{4}{ }^{2-}$ and $\mathrm{ClO}_{4}{ }^{-}$in $\mathrm{Mg} / \mathrm{Al}$-hydrotalcite, Am. Mineral. 87 (2002) 623-629. 


\section{$\underline{\text { Nitrate salts }}$}

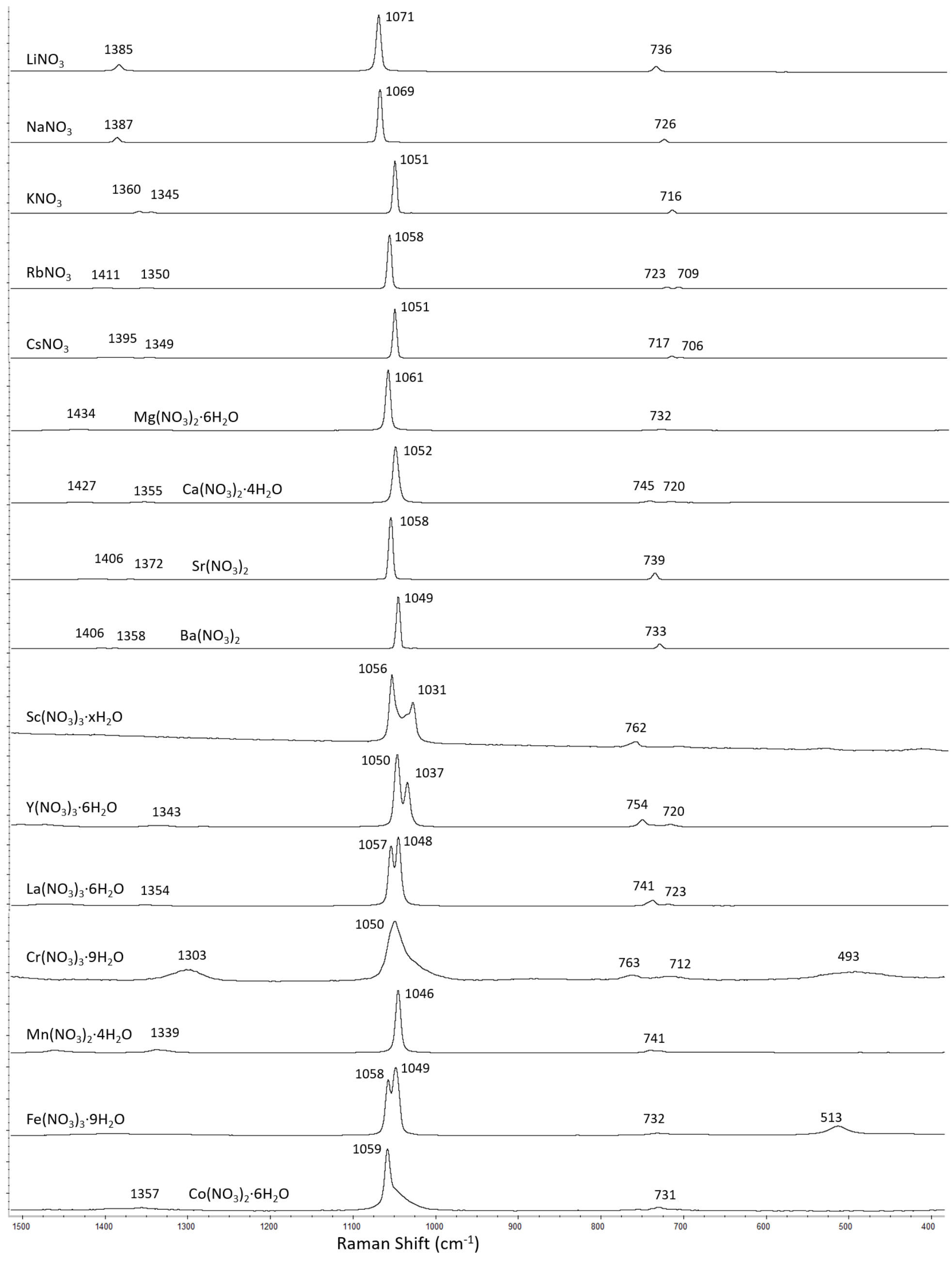




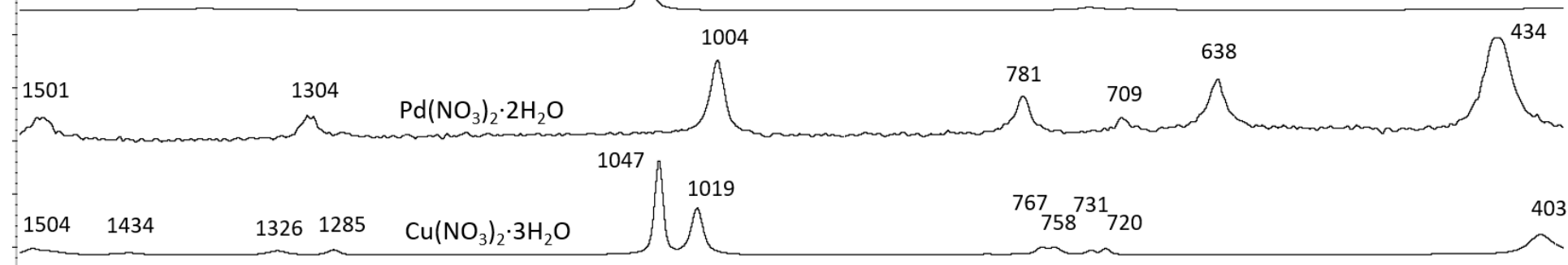

$\mathrm{AgNO}_{3} \quad 1347 \quad 734714$

$\mathrm{Zn}\left(\mathrm{NO}_{3}\right)_{2} \cdot 6 \mathrm{H}_{2} \mathrm{O} \quad 1353$

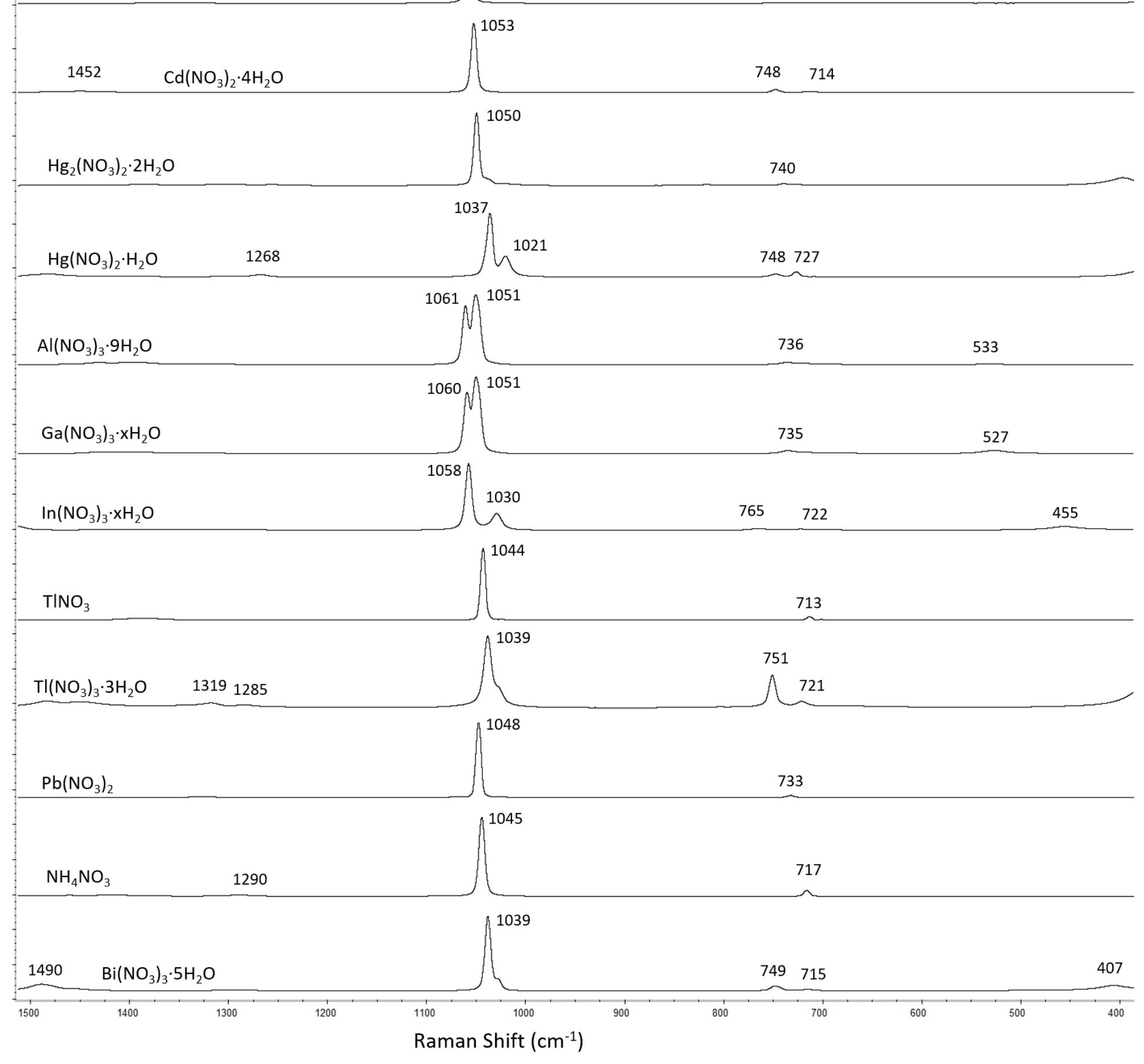




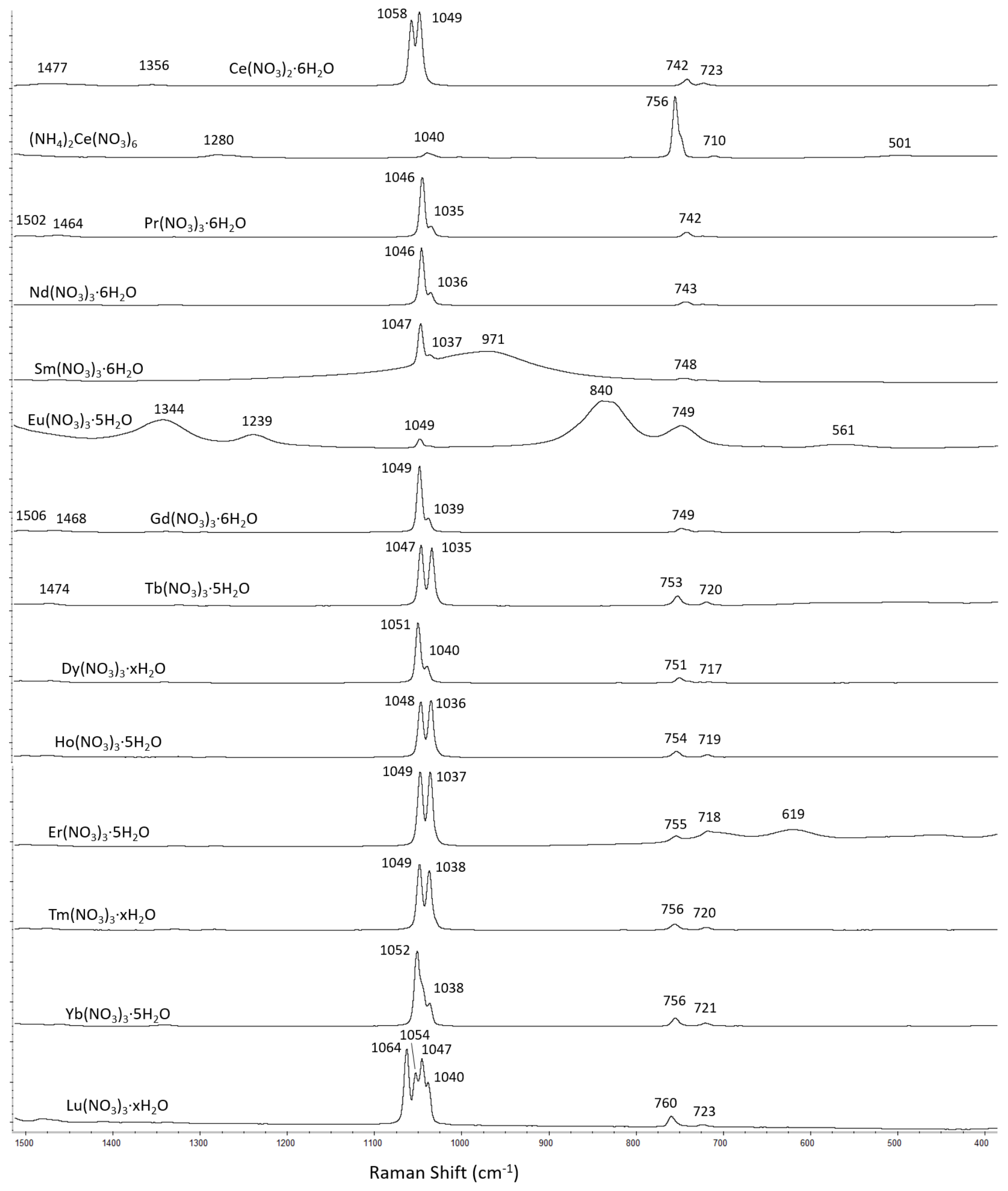




\section{Chlorate salts}

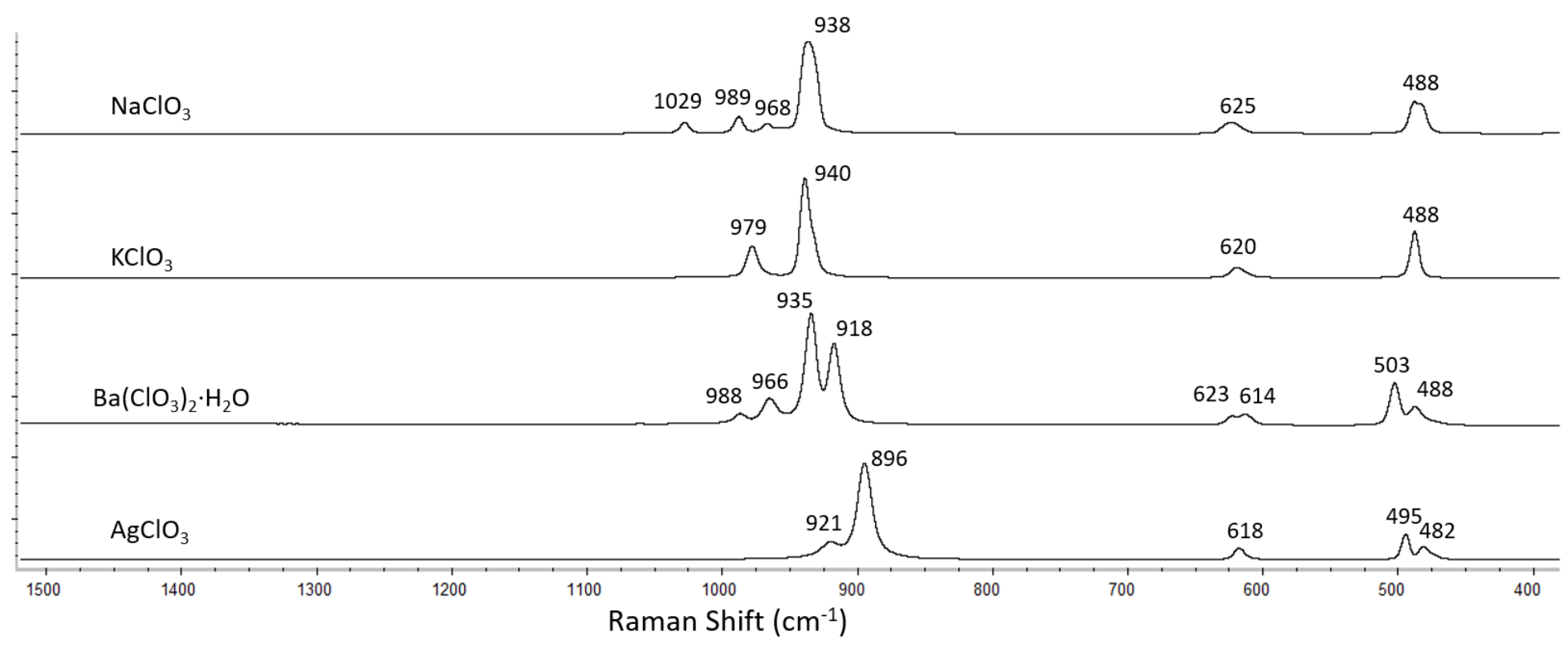




\section{Perchlorate salts}

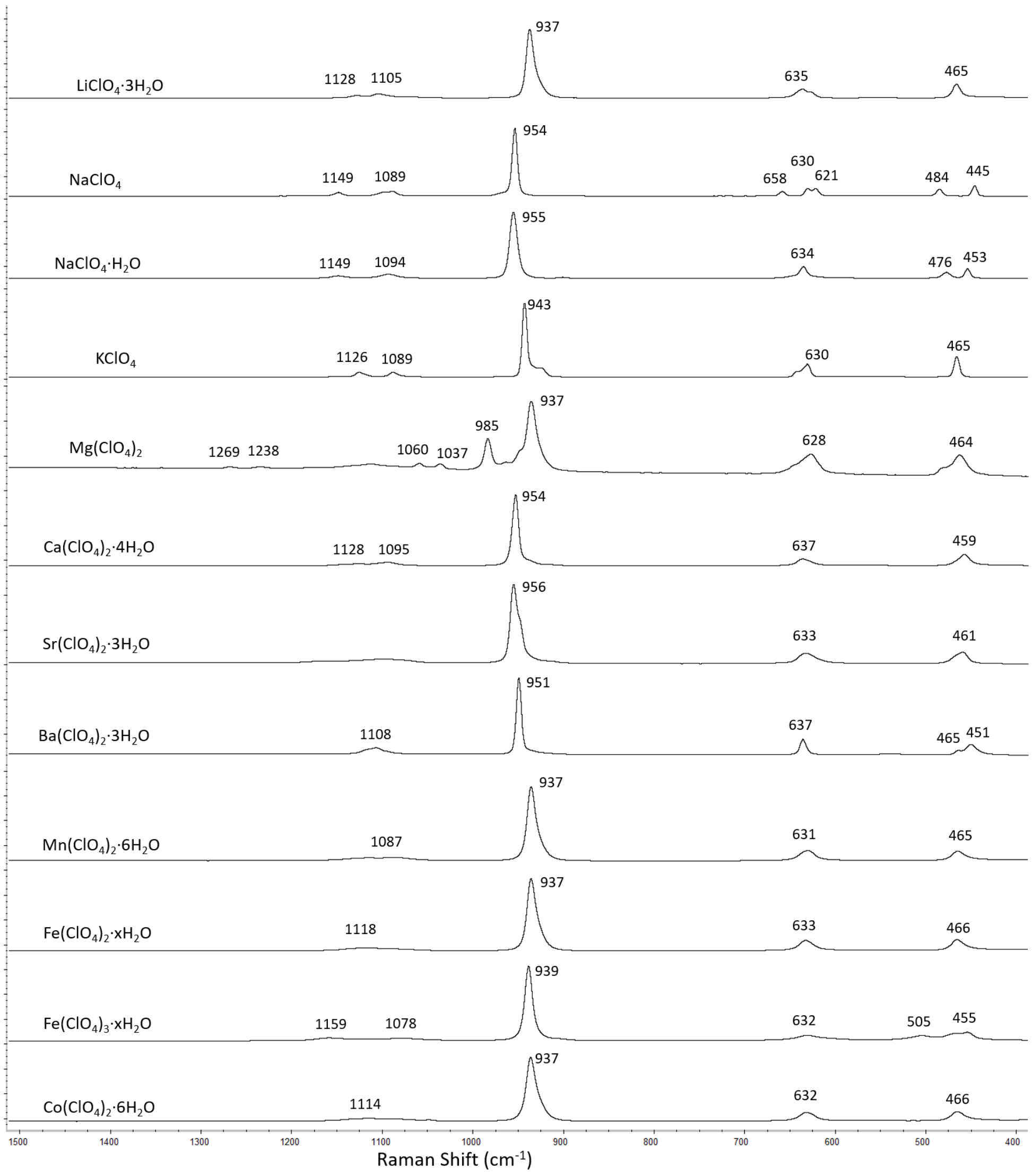




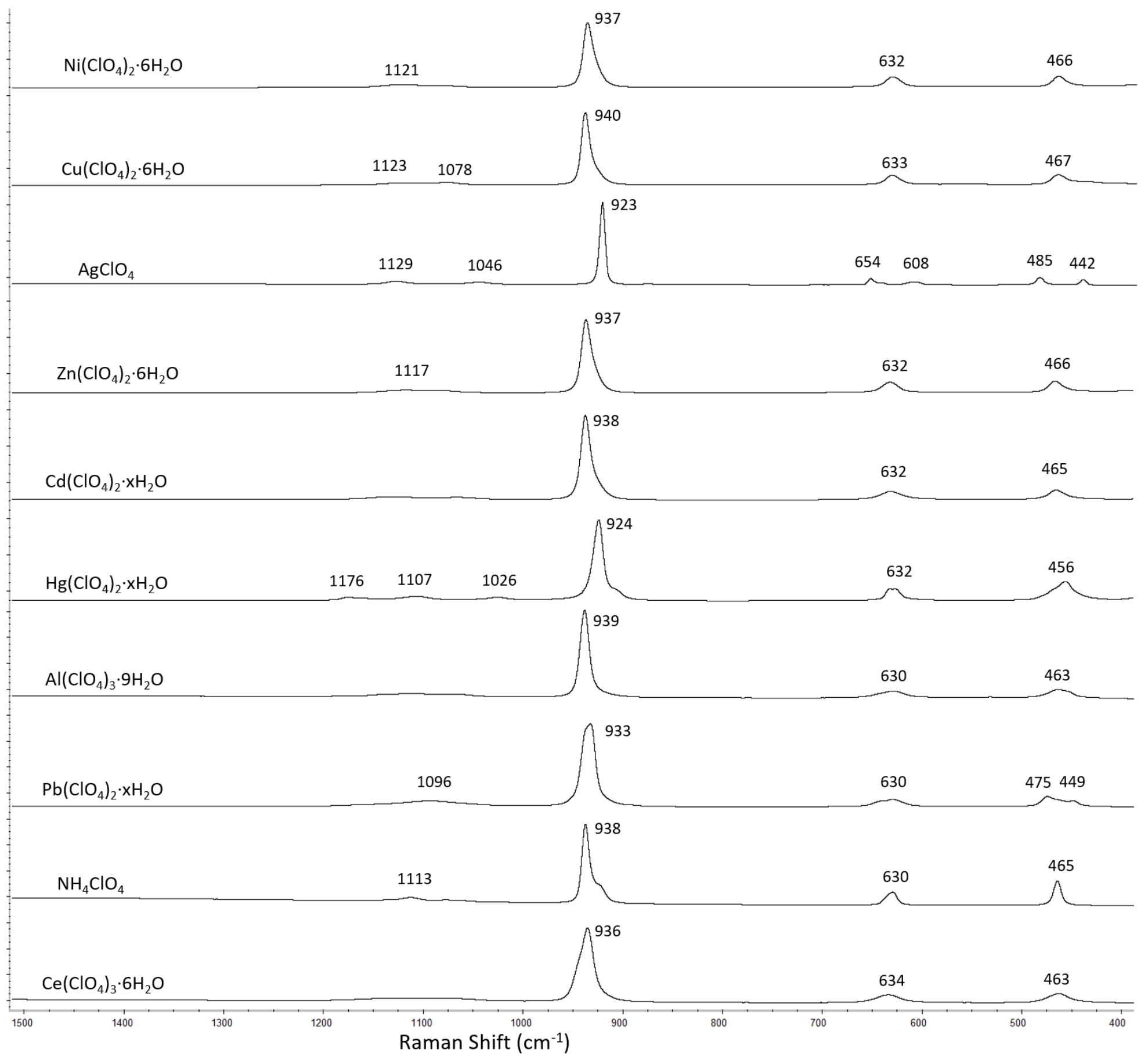




\section{Nitrate salts}

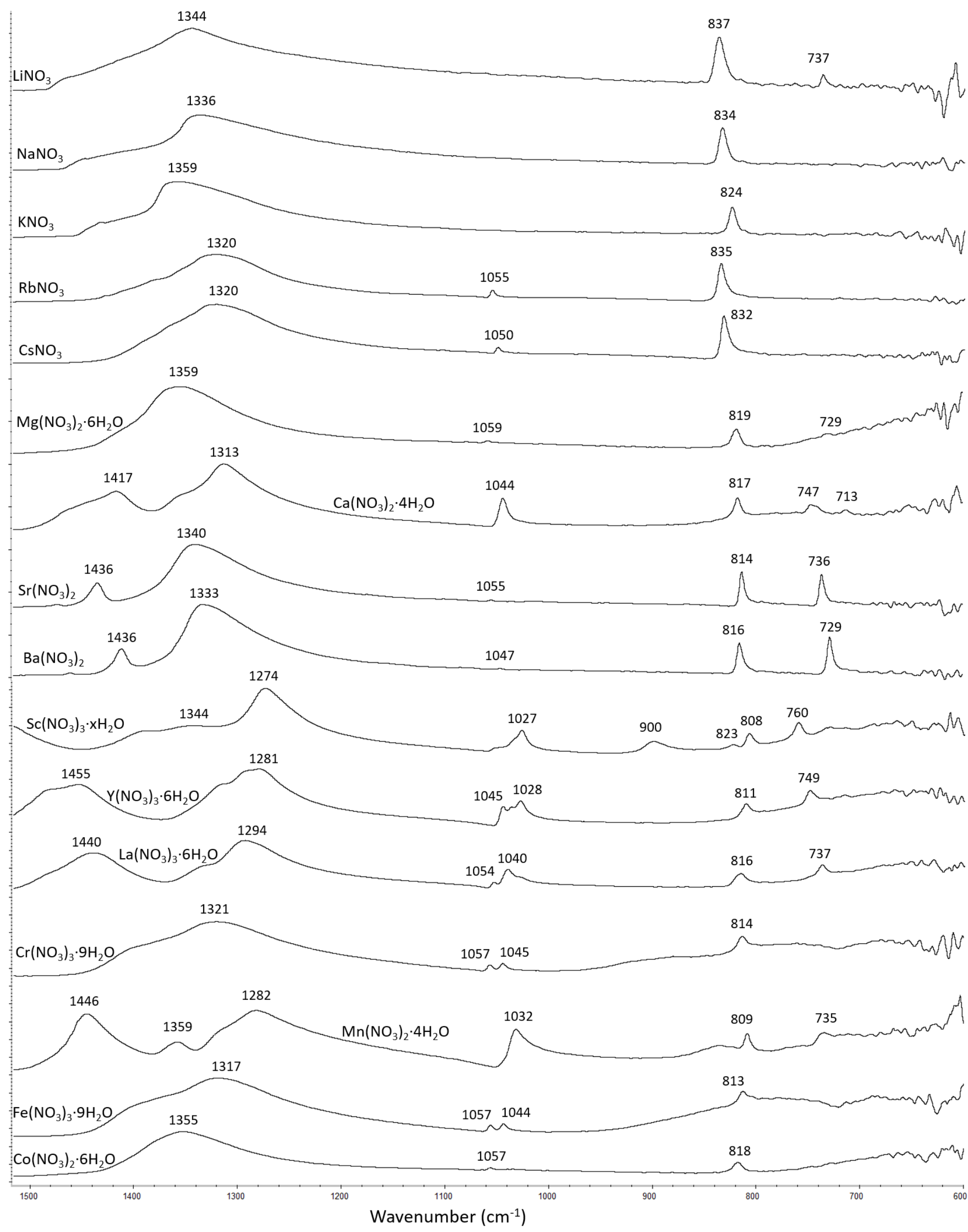



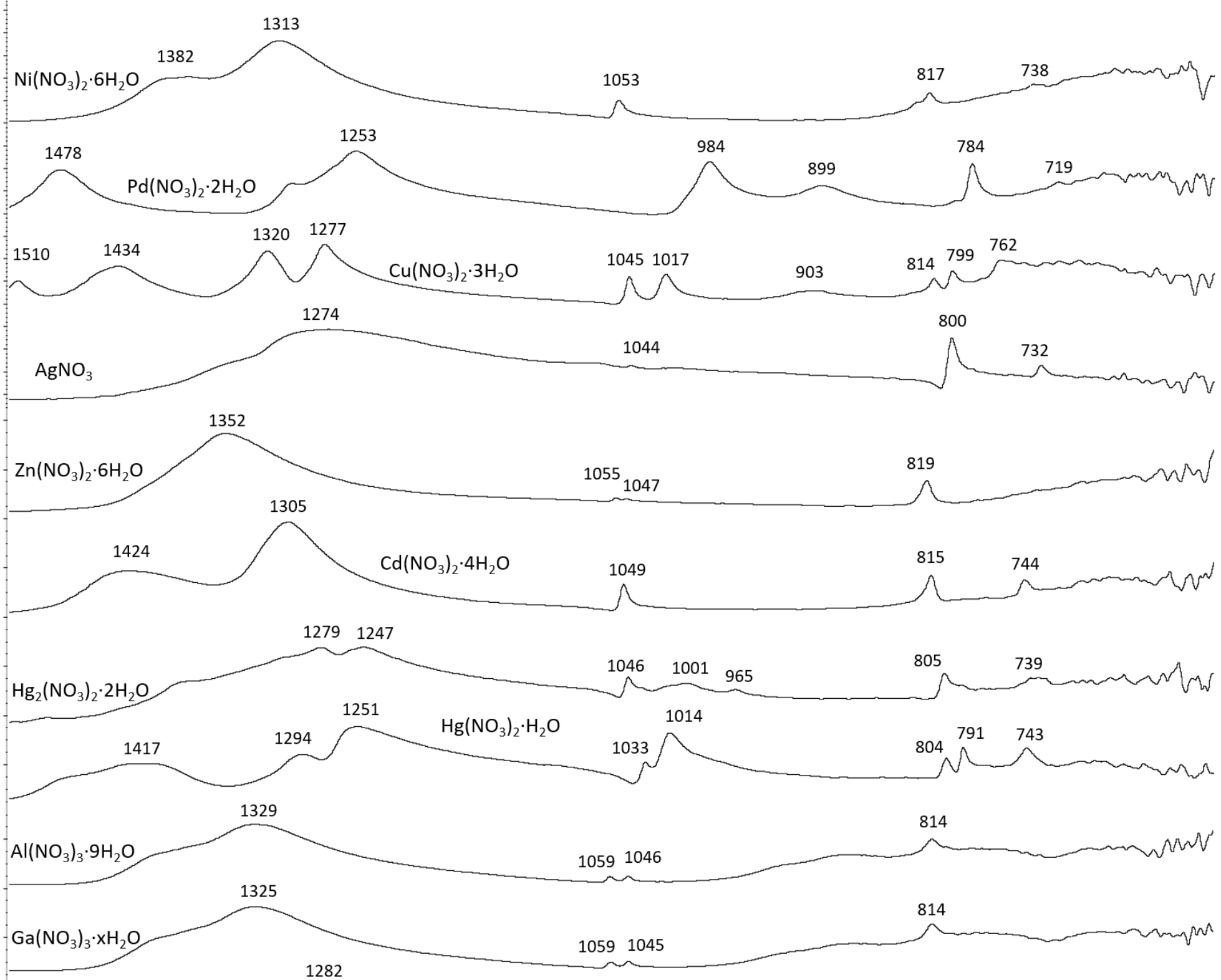

814

814
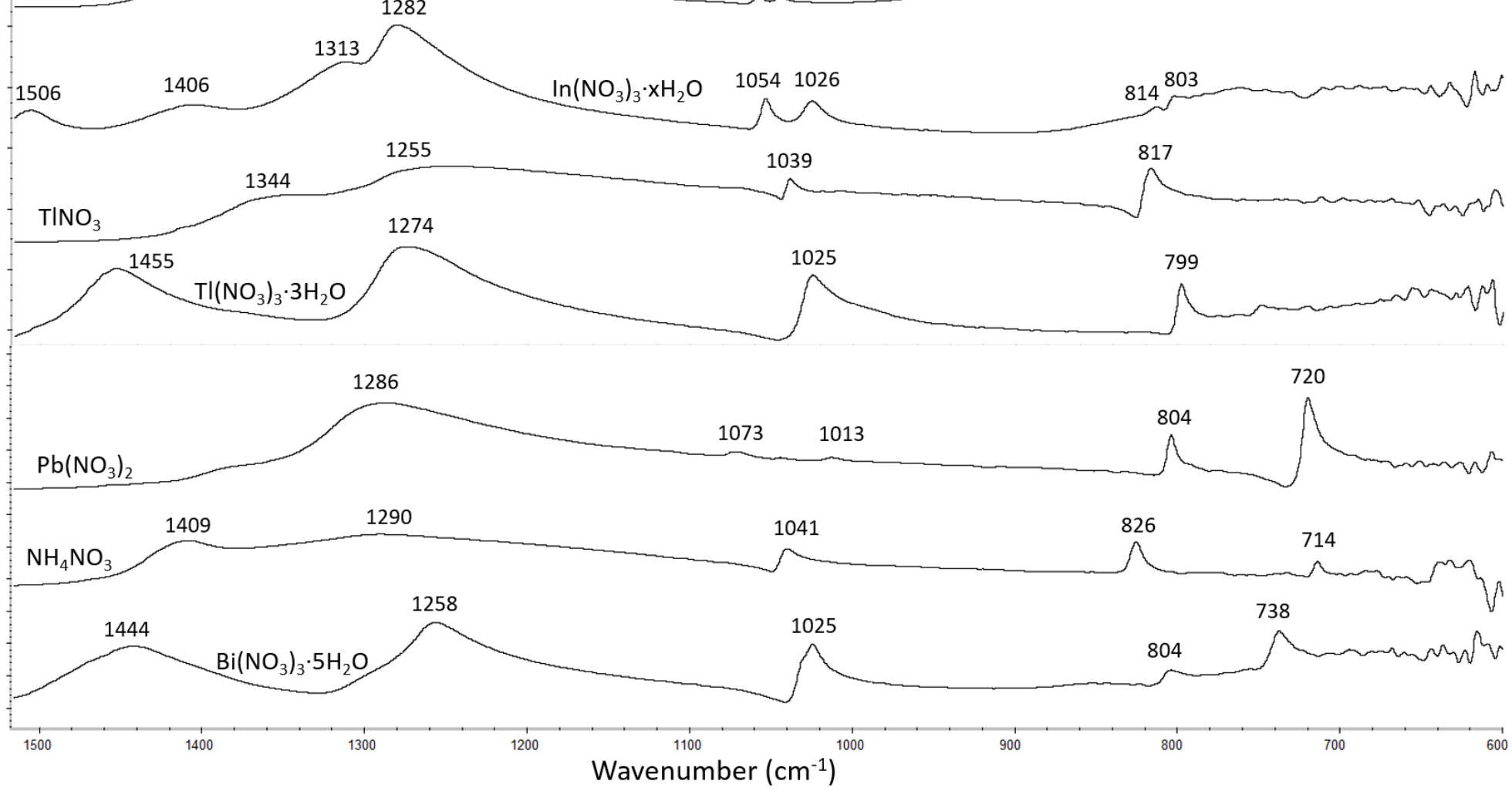


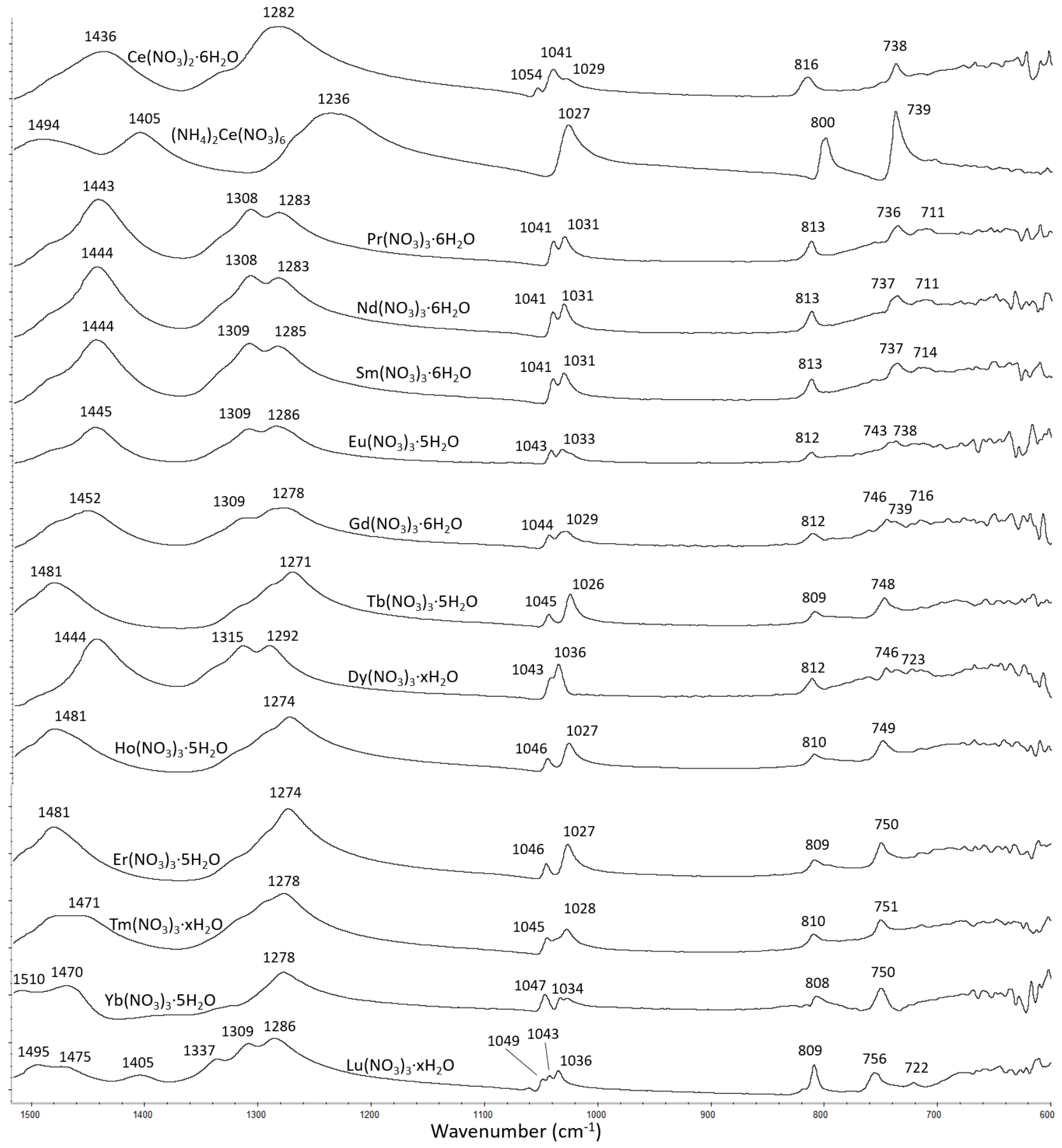




\section{Chlorate salts}

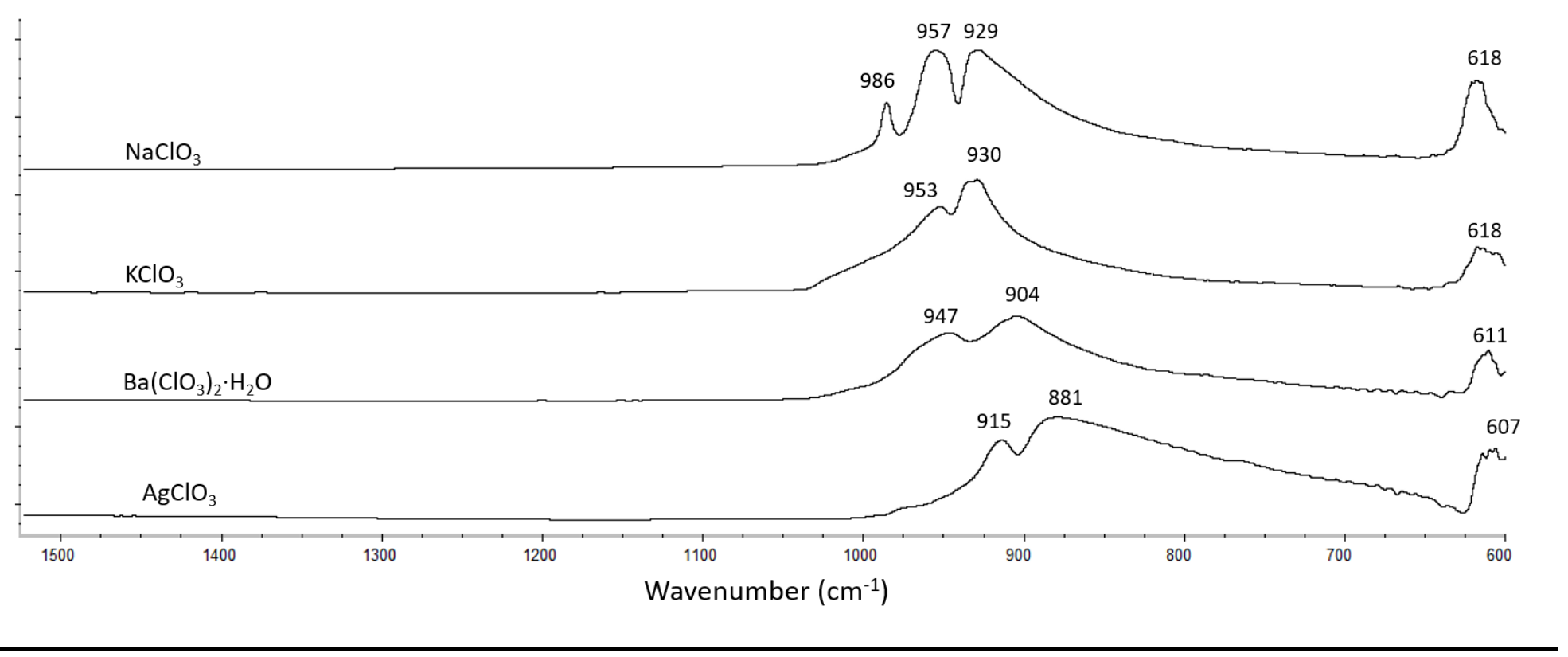




\section{Perchlorate salts}

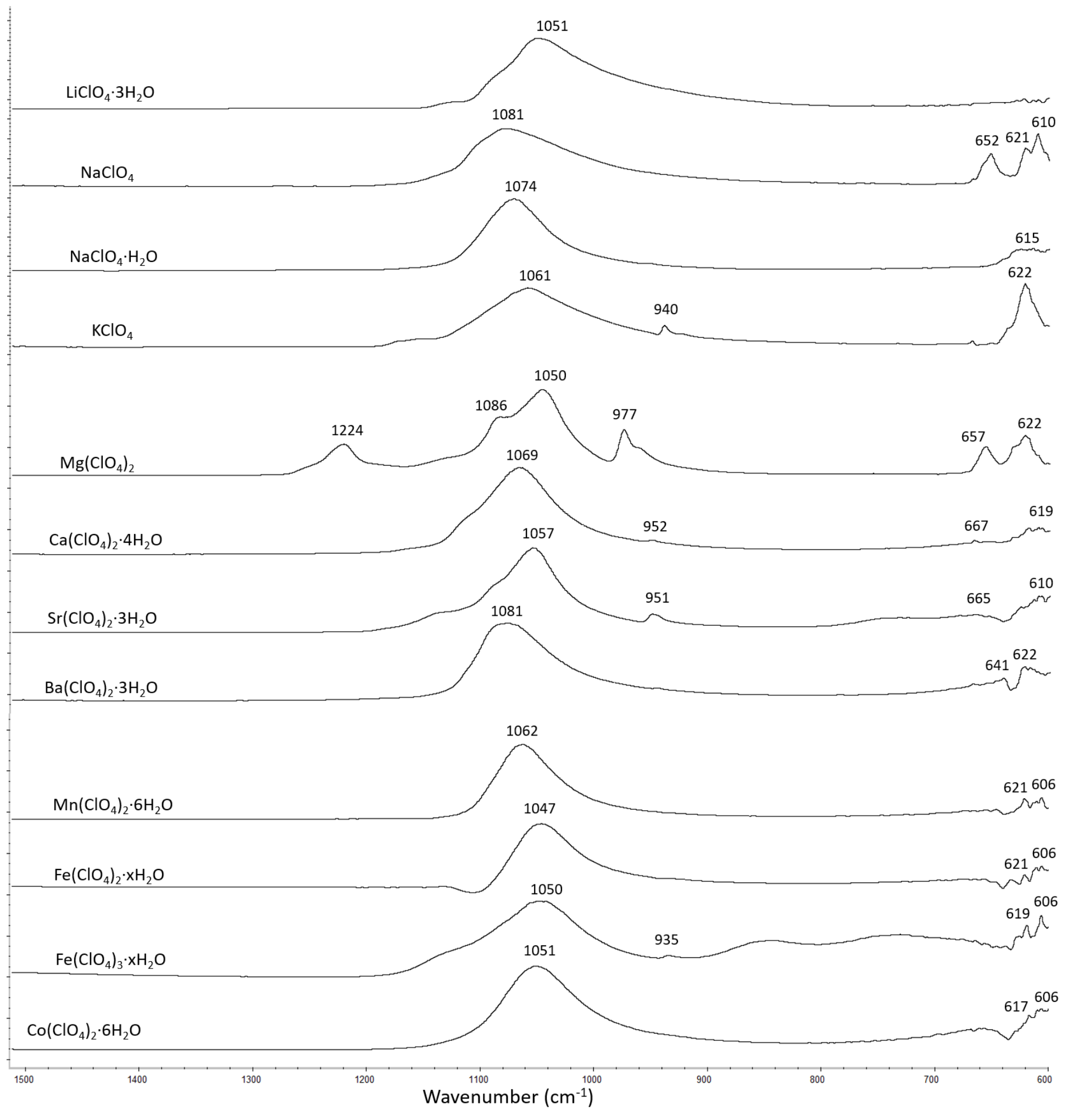




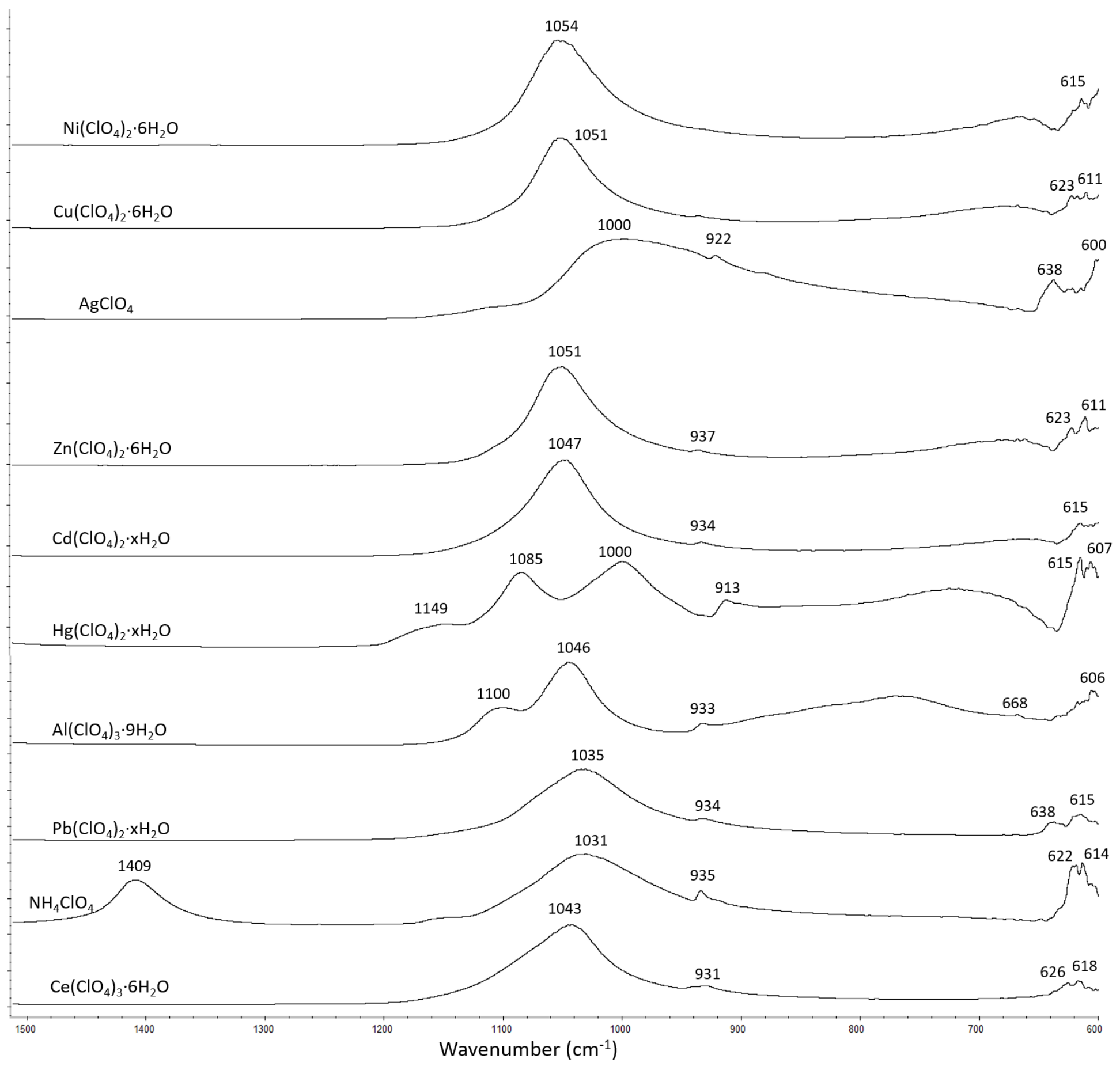

